\title{
Effects of physical disturbance on infaunal and epifaunal assemblages in subtropical, intertidal seagrass beds
}

\author{
Greg A. Skilleter ${ }^{1, *}$, Bronwyn Cameron ${ }^{1}$, Yuri Zharikov ${ }^{1}$, David Boland ${ }^{1}$, \\ Daryl P. McPhee ${ }^{1,2}$ \\ ${ }^{1}$ Marine and Estuarine Ecology Unit, School of Integrative Biology, University of Queensland, Brisbane, Queensland 4072, \\ Australia \\ ${ }^{2}$ Present address: Environmental Management Centre, School of Geography, Planning and Architecture, \\ University of Queensland, Brisbane, Queensland 4072, Australia
}

\begin{abstract}
We assessed the impact of large-scale commercial and recreational harvesting of polychaete worms Marphysa spp. on macrobenthic assemblages in a subtropical estuary in Queensland, Australia, by examining: (1) the spatial extent of harvesting activities and the rate of recovery of the seagrass habitat over an 18 to 20 mo period; (2) the recovery of infauna in and around commercial pits of known age; (3) the indirect effects of physical disturbance from trampling and deposition of sediments during harvesting on epibenthos in areas adjacent to commercial and recreational pits; (4) impacts of potential indirect effects through manipulative experimentation. Harvesting caused a loss of seagrass, changes to the topography and compaction of the sediments associated with the creation of walls around commercial pits, and the deposition of rubble dug from within the pit. The walls and rubble were still evident after 18 to 20 mo, but comprised only a small proportion of the total area on the intertidal banks. There was a shift from an intertidal area dominated by Zostera capricorni to one with a mixture of Z. capricorni, Halophila spp. and Halodule uninervis, but there was no overall decline in the biomass of seagrass in these areas. There were distinct impacts from harvesting on the abundance of benthic infauna, especially amphipods, polychaetes and gastropods, and these effects were still detectable after 4 mo of potential recovery. After 12 mo, there were no detectable differences in the abundances of these infauna between dug areas and reference areas, which suggested that infauna had recovered from impacts of harvesting; however, an extensive bloom of toxic fireweed Lyngbya majuscula may have masked any remaining impacts. There were no detectable impacts of harvesting on epifauna living in the seagrass immediately around commercial or recreational pits.
\end{abstract}

KEY WORDS: Bait harvesting · Physical disturbance $\cdot$ Intertidal Zostera $\cdot$ Macrofauna - Resale or republication not permitted without written consent of the publisher

\section{INTRODUCTION}

Seagrass meadows are an important component of coastal ecosystems, with levels of primary production that are among the largest for submerged aquatic communities (Hillman et al. 1995). Seagrasses are also important in regulating the physical, chemical and microbiological characteristics of the sediment (Mori- arty \& Boon 1989) and these systems support a diverse range of animals, including commercially important prawns and fish (Orth et al. 1984, Bell \& Pollard 1989).

Seagrasses are subjected to a large number of natural and anthropogenic perturbations (Shepherd et al. 1989), including physical disturbances such as wave action, recreational boating, trampling and storms (Zieman 1976, Dawes et al. 1997, Creed \& Amado Filh 
1999, Eckrich \& Holmquist 2000). In recent years, focus on understanding the implications of seagrass loss has become even more intense because of the worldwide decline in the distribution and health of seagrass beds (e.g. Shepherd et al. 1989, Short \& Wyllie-Echeverria 1996).

Harvesting of bloodworms (Polychaeta: Marphysa spp.) for use as bait occurs almost exclusively in intertidal Zostera seagrass beds because this is the habitat where the worms are commonly found (Day 1967, Fauchald 1977). Catching the worms damages the seagrass because the animals are infaunal, burrowing deep into the muddy sediments, and the seagrass must be dug over to harvest the worms. As such, bloodworm and similar fisheries attract attention from governments and environmental/conservation groups concerned about this damage and the implications for the plants and animals utilising the seagrass beds (see also Peterson et al. 1987). The large-scale nature of these operations also provides an opportunity to examine the effects of physical disturbance on seagrass communities at scales relevant to the management of these systems.

While there have been a number of studies examining different ecological impacts of bait-harvesting around the world (e.g. Klawe \& Dickie 1957, Blake 1979a,b, McLusky et al. 1983, de Boer \& Prins 2002, Zharikov \& Skilleter 2004), most of these have focussed on areas of unvegetated intertidal habitat. There is little detailed information on how baitharvesting affects vegetated habitats such as seagrass beds. The effects of other sources of physical disturbance (see references above) suggest that disturbance from activities associated with bait-harvesting are likely to impact significantly on seagrasses and associated fauna.

In this study, 4 major components of work are described. First, temporal changes in the physical structure of the seagrass habitat in and around areas that have been dug for bait were examined. Changes to attributes such as the structural complexity provided by seagrass have implications for other organisms, because many animals obtain a partial refuge from predation in this spatially heterogeneous habitat (e.g. Coen et al. 1981, Heck \& Thoman 1981, Summerson \& Peterson 1984, Leber 1985). Changes to the sediments (e.g. granulometry, compaction) as a result of digging may also influence the organisms that are found in these habitats because of the (often) close association between soft-sediment infauna and sedimentary parameters (e.g. Sanders 1958, 1960).

Second, the abundance of infauna in the sediments in and around large commercially dug pits of known age was examined to determine rates of recovery of the benthic assemblage in areas where seagrass had been disturbed through commercial harvesting. The nature of commercial bloodworm harvesting operations is similar to a small-scale dredging operation in that sediment is excavated and placed elsewhere, leaving large holes and pits in the surface of the substratum. The habitat is modified because gravel and rubble previously buried deep into the substratum is brought to the surface; topographic and structural complexity is changed both through this and the loss of seagrass. Rates of recolonisation of soft-sediment systems after physical disturbances such as dredging vary considerably, and range from 2 to 3 mo to several years depending on the system and the intensity and frequency of dredging operations (e.g. May 1973). Changes to the substratum during dredging may make areas less suitable for colonising larvae (Saila et al. 1972, Wildish \& Thomas 1985). Previous studies of recolonisation and recovery of the intertidal habitats used for commercial harvesting in Moreton Bay have only examined the vegetated components (i.e. the seagrass) of the system (e.g. WBM Oceanics 1993, Hopper 1994). There is no information available on the recovery of the fauna found in the affected seagrass beds.

Third, the abundance of larger ( $>1 \mathrm{~mm}$ size) epibenthic animals was determined in commercially harvested areas i.e. immediately adjacent to commercial pits, and in undisturbed, reference areas. The habitat examined was the area of intertidal seagrass that surrounded the commercial pits and was subjected to the indirect effects of disturbance primarily associated with the movement of the harvesters in and out of the pits and the deposition of sediments during excavation, rather than removal of the seagrass. The epibenthic component of the benthic assemblage is often not well represented in cores of sediment taken for examining the infauna, but these animals frequently have a close association with structures such as seagrass (Fonseca et al. 1990) and rubble (Dumbauld et al. 1993, Skilleter 1994) and so their distribution may be affected by changes to these components of the system.

Fourth, effects of small-scale physical disturbance on the intertidal seagrass beds were examined experimentally to determine whether the epibenthic assemblage was affected. These experimental manipulations were intended to complement the general sampling of the epibenthic fauna and were conducted in an area used for commercial harvesting, and also in an isolated area not used for commercial or recreational harvesting. Together, these 4 components were used to provide an integrated picture of how the physical disturbance associated with commercial and recreational bait harvesting affected the dynamics of the benthic assemblages in subtropical intertidal seagrass meadows. 


\section{MATERIALS AND METHODS}

Study sites. This study was conducted in Moreton Bay, Queensland, a large subtropical embayment on the east coast of Australia $\left(27^{\circ} \mathrm{S}, 153^{\circ} \mathrm{E}\right.$; Fig. 1). The commercial harvesting of bloodworms Marphysa spp. is restricted by fisheries legislation to 4 areas on Fisherman's Island, at the mouth of the Brisbane River (Fig. 1). Two of these commercial areas (at the northern and southern ends of the Island: Commercial Area 1 and Commercial Area 4, Fig. 1) were sampled to examine temporal changes in the composition of the habitat and the effects of harvesting on the infauna and epifauna. The 2 commercial areas sampled are the most important in terms of total bloodworm harvest and harvesting effort. Commercial pits on Fisherman's Island consist primarily of a raised wall (dyke) surrounding an area of variable size from which the animals are dug with a pitchfork. Water is bailed from inside the dyke with buckets or, in some cases, with petrol-driven hydraulic pumps. Digging continues within the confines of the pit walls until the incoming tide breaks the dyke and floods the area.
Recreational harvesting is allowed elsewhere in Moreton Bay, but not on Fisherman's Island. For the recreational harvesting of bloodworms, commercial style 'bail and dyke' pits may be dug, but more usually the less time-consuming and physically easier method of digging 'trenches' or 'pot holes' with a standard garden fork is used. The main area in western Moreton Bay used by recreational fishers (G. A. Skilleter unpubl.) is along the foreshore of Wynnum-Manly, in close proximity to Fisherman's Island (Fig. 1), so the effects of harvesting on epifauna were also examined here. The effects of physical disturbance on epibenthos in intertidal seagrass beds were examined in manipulative experiments completed on the intertidal mudflats at Fisherman's Island (western Moreton Bay) and on North Stradbroke Island (eastern Moreton Bay). Two sites, approximately $1 \mathrm{~km}$ apart, were used on Fisherman's Island close to Commercial Area 1 (Fig. 1), in an area that had extensive coverage of Zostera capricorni but was at least 100 to $150 \mathrm{~m}$ from the nearest commercial pit. Commercial fishers were notified of the experiments and their position on the Islands so they could avoid disturbing these areas. Two sites,

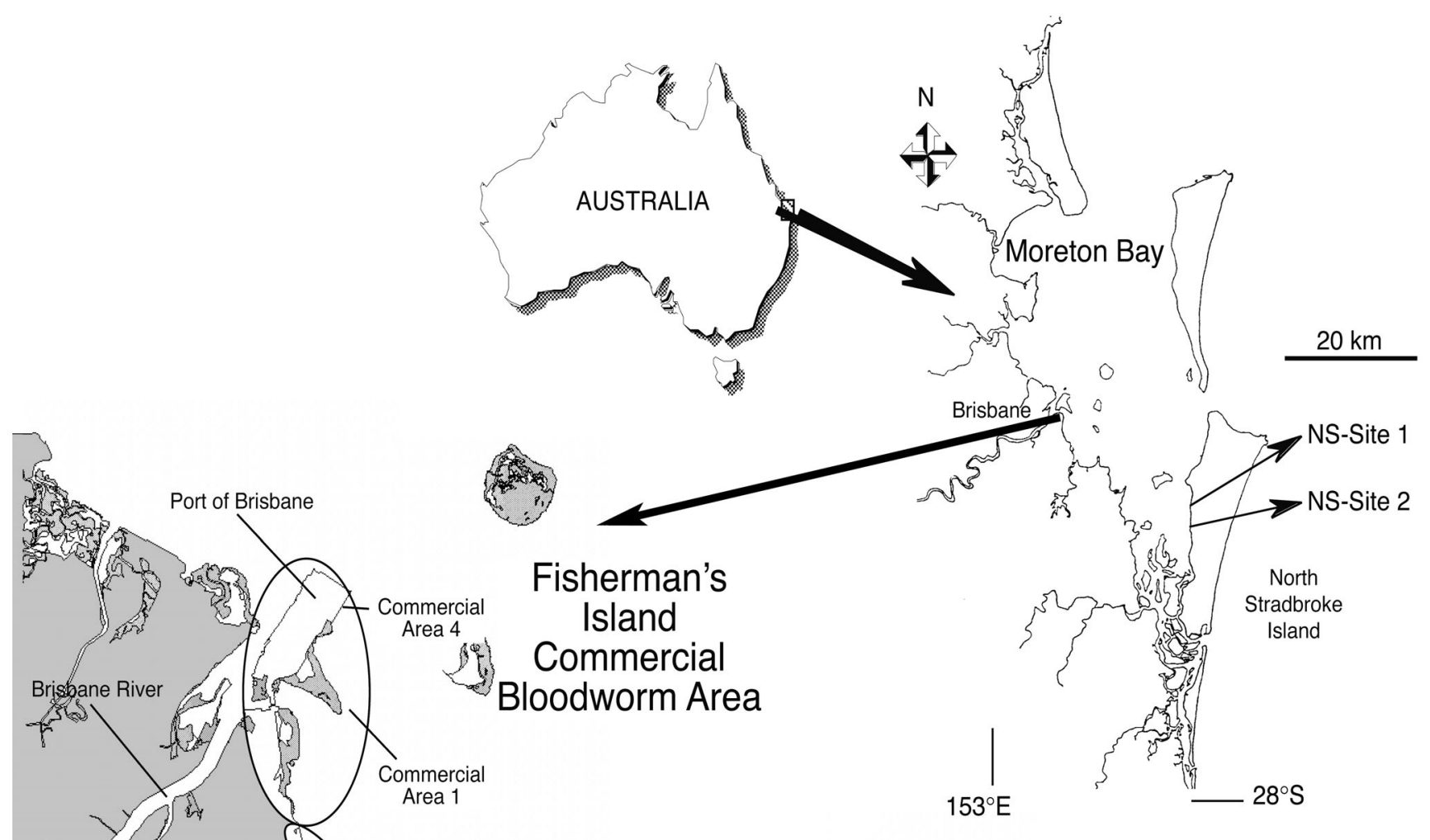

Fig. 1. Australia and the Moreton Bay region of SE Queensland, showing locations of the Fisherman's Island commercial bloodworm harvesting areas, the Wynnum-Manly foreshore used by recreational harvesters, and the sites on North Stradbroke Island (NS-Site 1 and NS-Site 2) used for the experimental examination of the effects of disturbance on epibenthos 
hereafter NS-Site 1 and 2 (Fig. 1) and approximately 2 $\mathrm{km}$ apart, were also used on North Stradbroke Island. These sites were distant from areas generally accessed by the public and the experiments were therefore unlikely to be disturbed.

Habitat composition and dynamics. The distribution and relative abundance of different substrata in and around commercial pits on Fisherman's Island was estimated along each of 5 transects that extended for $200 \mathrm{~m}$ from the the high tide mark across an area previously dug by commercial bait-harvesters. When the initial mapping was completed (August 1999), commercial harvesters were working 500 to $600 \mathrm{~m}$ east of the area examined; they indicated that this area would not be re-visited for some time given that it had been worked within the last 2 to 3 mo. Commercial operators voluntarily leave areas for approximately 18 to 24 mo before re-harvesting to allow for recovery of the seagrass (authors' pers. comm.).

Transects were approximately $100 \mathrm{~m}$ apart, but their position was chosen at random. Nine categories of substratum were defined on the basis of initial observations (Table 1). Some categories, such as 'seagrassZostera', were relatively broad in terms of the range of substrata that fell within the category: e.g. 'seagrassZostera' did not distinguish between dense and sparse seagrass. Variations in characteristics of the substrata within these categories were quantified in more detail through examination of the biomass of vegetation within the patch (see below). The extent of each type of substratum crossed by each transect was measured to the nearest centimeter. Transects were sampled initially in August-September 1999 and then again 20 mo later in April-May 2001. This interval was chosen on the basis of the time-period commercial harvesters claimed to leave an area fallow before it was reharvested for worms.

Sediment compaction: The compaction of sediment along each transect was determined using a penetrometer constructed from a $50 \mathrm{~cm}$ long rod of stainless steel, weighing approximately $280 \mathrm{~g}$. The rod was dropped from a constant height of $1.3 \mathrm{~m}$ above the substratum, inside a narrow PVC tube to ensure it struck the surface at a perpendicular angle, and the depth to which it penetrated the sediment was used as an index of the relative compaction of the sediment. Five to 10 measurements were made within a $1 \mathrm{~m}^{2}$ quadrat located along the transect on either side of a transition from one substratum category to another.

Seagrass characteristics: Cores of sediment were collected to determine the above- and below-ground biomass of seagrass in each patch of substrata category crossed by a transect. Within commercial pits, cores were only collected from sections that were undug. The section of the pit that had been dug was usually 1 to $1.5 \mathrm{~m}$ deeper than the surrounding area and was filled with soft mud. The cores that were collected in the undug section therefore represent the seagrass in the pit prior to it being harvested, or after recolonisation had begun. Sections of the pits were often left undug in order to facilitate this recolonisation (commercial harvesters pers. comm.), although it was clear that not all harvesters did this (see 'Results'). Cores were $15 \mathrm{~cm}$ in diameter and taken to a depth of $10 \mathrm{~cm}$, below which there was rarely any below-ground seagrass root material.

Variable numbers of replicate cores were collected dependent on the length of the patch of habitat. At

Table 1. Major categories of substratum along $200 \mathrm{~m}$ transects at Fisherman's Island, and crossing the main areas used by commercial bait-harvesters

\begin{tabular}{|c|c|}
\hline Substratum category & Criteria for category \\
\hline Seagrass-Zostera & Primarily Zostera capricorni, with less than $5 \%$ coverage of other seagrass species and/or algae \\
\hline Seagrass-mixed & Mixture of Zostera capricorni, Halodule uninervis, Halophila ovalis and Halophila decipiens \\
\hline Seagrass-algae & $\begin{array}{l}\text { Mixture of Zostera capricorni and macroalgae, mostly Gracilaria, Laurencia, Colpomenia } \\
\text { sinuosa, Hydroclathrus clatharatus and Padina fraseri }\end{array}$ \\
\hline Wall & $\begin{array}{l}\text { Raised wall or dyke created using the bail-and-dyke method. Walls consist primarily of coarse } \\
\text { rubble and shell fragments when the intermixed sediment washes away on the rising tide }\end{array}$ \\
\hline Wall: seagrass & An area of wall where Zostera capricorni has re-grown \\
\hline Pit & $\begin{array}{l}\text { An area of habitat, surrounded by walls, from which seagrass has been dug over for worms. } \\
\text { Characterised by the presence of the surrounding walls and deep holes }\end{array}$ \\
\hline Trench & $\begin{array}{l}\text { A narrow channel immediately outside the walls surrounding a pit, formed when the walls are } \\
\text { being dug for the bail-and-dyke method of harvesting }\end{array}$ \\
\hline Rubble & $\begin{array}{l}\text { Patches of habitat characterised by piles of shell material lying on the surface of the mud in } \\
\text { close proximity to pits }\end{array}$ \\
\hline Bare sediment & $\begin{array}{l}\text { Areas without coverage of vegetation (seagrass or algae) or obvious amounts of shell rubble on } \\
\text { the surface }\end{array}$ \\
\hline
\end{tabular}


least 1 sample was collected from each metre of substratum for each patch (e.g. 10 replicate samples from a $10 \mathrm{~m}$ length), with a minimum of 3 samples collected from each patch. The cores of sediment were placed into labelled plastic bags and frozen pending procession in the laboratory. Each species of seagrass was separated into above- and below-ground components, which were then dried (approximately $72 \mathrm{~h}$ at $70^{\circ} \mathrm{C}$ ) and weighed. Macroalgae were also separated into species and dried and weighed.

Commercial pits: For each of the commercial pits encountered along transects, additional information was collected to describe the size, depth, and height of all walls and the presence and size of any gaps in the walls. The latter variable was collated after discussions with commercial harvesters, who indicated that it was widely believed that that fishers must breach the walls that are formed around a pit once the pit has been dug over because it facilitated more rapid recovery of the seagrass. It was evident during initial visits to the commercial areas that not all commercial harvesters were doing this. The height of each of the walls was measured on the inside and outside edges at 5 equally spaced points along the walls.

Analysis of habitat data: The 5 transects crossed areas of intertidal habitat that were each visibly different in general character (height above sea level, gradient, degree of previous harvesting, etc.). Analysis of data on the composition of the habitat was conducted separately for each transect and time using 1-way ANOVAs to test for differences in physical characteristics among the different habitat types. These analyses were unbalanced because of the different number of readings taken depending on the overall length of the habitat along the transect. Post-hoc Student-NewmanKeuls (SNK) tests were completed to compare among means where ANOVA indicated significant differences in compaction among habitat types.

Infauna and commercial pits. Pits being dug by commercial operators were tagged on the day the pit was first opened. Tags were placed in each corner of the pit and the harvesters were asked not to move or bury the tags. Tag recovery was almost $100 \%$. The abundance of infauna in and around commercial pits and in reference areas away from the area used by commercial operators was determined from cores of sediment associated with pits of different ages. Five replicate cores of sediment, each $15 \mathrm{~cm}$ diameter $\times 15 \mathrm{~cm}$ depth, were collected from each of 5 different treatments: (1) inside a commercial pit of known age; (2) from the surrounding walls (dyke) of the pit; (3) outside the pit but within 10 to $15 \mathrm{~cm}$ of the wall; (4) from undug areas (primarily seagrass) at least $10 \mathrm{~m}$ from the nearest pit but still within the area available to commercial operators (internal reference area); and (5) from undug areas outside the area available to commercial operators (external reference area). Thus, 25 samples were collected for each of the pits of known age. Samples from the internal reference area were collected to measure any small-scale indirect effects on abundance and community composition of the infauna from the commercial operations. These samples were collected from patches of seagrass where there were no obvious signs of recent digging (e.g. no rubble on the surface, walls or small pits), but were still within the area available to commercial operators. Samples from the external reference area were taken at least $200 \mathrm{~m}$ from any signs of commercial activity and outside the designated area available to harvesters.

Sampling caused considerable disturbance to the habitats in and immediately around the commercial pits. The substratum was soft and easily churned when walked on, and it was impossible to collect samples without sinking into the mud. Replicate samples were separated by at least $1 \mathrm{~m}$ to avoid collecting sediment from an area that had been disturbed while collecting the previous replicate. To avoid artifacts associated with repeated sampling of the same pits (Skilleter 1996), each pit was only sampled once. Sufficient pits were tagged to allow a new set of 2 pits to be sampled 1, 2, 4 and 12 mo after the initial disturbance.

At the time the 12 mo old pits were sampled, there was extensive coverage of fireweed Lyngbya majuscula over Fisherman's Island. L. majuscula is also thought to affect a range of different marine organisms that come in contact with or consume it (Dennison et al. 1999). There were noticeably fewer animals than seen previously on the surface of the substratum (see 'Results'), and inspection of several sediment cores indicated there were also fewer infaunal animals. On this occasion, 4 pits were sampled, but (1) 4 instead of 5 replicate cores were taken from each of the habitat types, (2) samples were not collected from the internal reference area, and (3) samples were collected from 8 external reference areas rather than 4 . This increase in sampling intensity was intended to determine the extent of the apparent effects of the L. majuscula bloom. The continued presence of the L. majuscula bloom in the study area and associated human health concerns (see Osborne et al. 2001) meant that further sampling of pits was abandoned.

Samples were placed into sealed jars and returned to the laboratory where they were fixed in a $7 \%$ formalin solution containing the vital stain Bengal Red and left for at least $72 \mathrm{~h}$. Samples were then washed to remove formalin and stored in $70 \%$ ethanol until processing. They were sieved across a $1 \mathrm{~mm}$ sieve and the animals retained on the sieve identified and counted.

Data were analysed with 1-factor ANOVA to compare the abundance of different taxa in each of the 
5 treatments. The data associated with a single pit of known age (treatments: [1] inside the commercial pit, [2] the surrounding walls and [3] outside the pit but within 10 to $15 \mathrm{~cm}$ of the wall; $\mathrm{n}=5$ replicates for each) were compared with the combined data for both the internal and external reference areas ( $\mathrm{n}=10$ replicates), resulting in an unbalanced design. This was done because the commercial pits were not opened on the same day (even though they were the same age when sampled), they varied considerably in size and depth, and were often spatially separated from each other. Initial analysis on the abundance of animals in pairs of pits of known age indicated that they were significantly different from each other on almost all occasions.

Epibenthos and commercial pits. Samples of the epibenthos were collected in 3 different regions used for the harvesting of bloodworms (Fig. 1). Commercial Area 1 (southern end of Fisherman's Island) and Commercial Area 4 (northern end of Fisherman's Island) are the 2 most important commercial harvesting plots in Moreton Bay, accounting for over $75 \%$ of total commercial harvest of bloodworms in the region (G. A. Skilleter unpubl.). Wynnum-Manly is the area in Moreton Bay most heavily accessed by recreational harvesters.

Samples were collected from the area of seagrass immediately surrounding the commercial pits rather than inside the pits; initial sampling indicated that trampling and digging in the pits resulted in all epibenthos either being buried or leaving the pits, and not recolonising until the surrounding walls had collapsed and the pit had almost completely merged with the surrounding substratum (see 'Results'). Sampling of the area around the pits examined whether there were indirect impacts from harvesting on the epibenthos in the seagrasses close to the commercial operations. Only pits with fully intact walls were selected. Eight pits were sampled in Commercial Plot 1, 3 pits in Commercial Plot 4 and 3 pits in the Wynnum-Manly recreational area. At each of the harvested sites (pits) examined, 5 replicate samples were collected from around the commercial pit, i.e. from 10 to $50 \mathrm{~cm}$ from the edge of the pit wall. Five haphazardly positioned, replicate samples were also collected from each of an equal number of reference sites. Reference sites were positioned in the area of Fisherman's Island that was not available to commercial operators for digging, and/or in areas generally inaccessible to recreational harvesters.

Each sample comprised all the material to a depth of approximately $5 \mathrm{~mm}$ into the substratum from within a $1 \mathrm{~m}^{2}$ quadrat. Data were analysed with 2-factor, mixed model analysis of variance (ANOVA), with factors Habitat (fixed: Pits vs. Reference) and Sites (nested within Habitat). Data were examined separately for each of the 3 regions. The composition of the epibenthic assemblage was compared between the com- mercial/recreational pits and reference sites using PRIMER and 2-factor analyses of similarities (ANOSIM) on untransformed and 4th root transformed data and plotted using non-metric multidimensional scaling (nMDS).

Experimental manipulations of disturbance and epibenthos. To determine the effects of physical disturbance on the epibenthic assemblage, patches of intertidal seagrass and sediment (each $1 \mathrm{~m}^{2}$ in area) were experimentally manipulated. Three levels of disturbance were created at the sites on North Stradbroke Island, an area where there is no commercial bait harvesting. 'High Disturbance' plots were created using a pitchfork of the same sort used by bait harvesters, with the tines pushed approximately $20 \mathrm{~cm}$ into the sediment to loosen the sediment and the associated roots and rhizomes of the seagrass, although no seagrass was removed. The sediment and seagrass in these patches were trampled and disturbed during this process in a manner consistent with harvesters moving around an area. This treatment was intended to simulate the disturbance associated with preliminary digging of commercial pits, when commercial operators tested intertidal areas prior to determining the location of the pit. 'Low Disturbance' plots were created by moving the superficial sediments around with the tines of the pitchfork but leaving the seagrass intact. This treatment was intended to test whether any effects of disturbance in the High Disturbance plots were a specific result of damage to the seagrass. 'Control' plots were not disturbed with the pitchfork. Only 2 levels of disturbance (High Disturbance and Control) were used on Fisherman's Island. For each treatment, 4 replicate $1 \mathrm{~m}^{2}$ patches were established at each site. The 3 different treatments on North Stradbroke Island were sampled 8 and 21 wk after disturbance (total of 48 patches: 2 times $\times 2$ sites $\times 3$ treatments $\times 4$ replicates). The treatments on Fisherman's Island were only sampled after $8 \mathrm{wk}$.

Epibenthic macrofauna were collected from a $0.25 \mathrm{~m}^{2}$ quadrat positioned in the centre of each $1 \mathrm{~m}^{2}$ experimental patch. Only the smaller central area of each patch was sampled to reduce the likelihood of edge effects (Bowden et al. 2001). First, all large and easily visible animals such as mud whelks Pyrazus ebeninus, sentinel crabs Macrophthalmus spp., and the yellow-striped hermit crab Clibanarius taeniatus were collected by hand. Second, the above-ground seagrass was removed (without uprooting the plants) to expose the sediment surface. Smaller animals were then collected by lightly brushing the surface of the mud into a small dustpan. This material was added to the plucked seagrass and washed across a $1 \mathrm{~mm}$ sieve before being preserved in a $5 \%$ formalin/seawater solution containing the red stain Rose Bengal. 
Two $\times 10 \mathrm{~cm}$ diameter cores of seagrass were collected with a PVC corer pushed to a depth of $20 \mathrm{~cm}$ from the area outside the central quadrat to determine the biomass of seagrass in each experimental patch. The seagrass was washed across a $1 \mathrm{~mm}$ sieve, and separated into above-ground (shoots) and below-ground (roots and rhizomes) components that were then dried separately for $72 \mathrm{~h}$ at $70^{\circ} \mathrm{C}$ before being weighed.

\section{RESULTS}

\section{Habitat composition \\ Qualitative changes}

The study area was harvested just prior to the first survey (August 1999), but no additional pits were dug during the 18 mo of monitoring. Many of the pits along the transects were of a known age ( 1 to 2 mo old) as they were tagged on the day they were opened. Therefore, the characteristics of the habitats along the transects in August 1999 reflected the condition in an area recently dug by commercial harvesters, with only a short recovery period. At the end of the study, all the pits along the transects were at least 18 mo old and provided a broad baseline against which to assess recovery of the habitat.

There were marked qualitative changes to the type of substratum along the transects over the course of 18 mo. Along 4 of the 5 transects, there was a shift from patches dominated by Zostera capricorni to substratum dominated by either a mixture of different seagrass species (seagrass-mixed, Fig. 2A,C), or seagrass with abundant macroalgae (seagrass-algae, Fig. 2A). In this and subsequent figures, plots are presented for only some of the 5 transects, selected to show the full range of changes in habitat composition that was documented. The changes along other transects fell within this range so have not been shown. On the remaining 5th transect (Fig. 2B) the coverage of $Z$. capricorni increased, but there was no increase in the proportion of other species of seagrass or macroalgae. Over the course of the $18 \mathrm{mo}$, the extent of area covered by commercial pits along the transects either changed very little (e.g. Transect 1, Fig. 2A; Transect 4, Fig. 2C) or the pits became indistinguishable from the surrounding substratum (Transect 3, Fig. 2B).

\section{Sediment compaction}

In August 1999, the different habitats varied in the degree of compaction of the substratum, but the magnitude of any differences varied from transect to
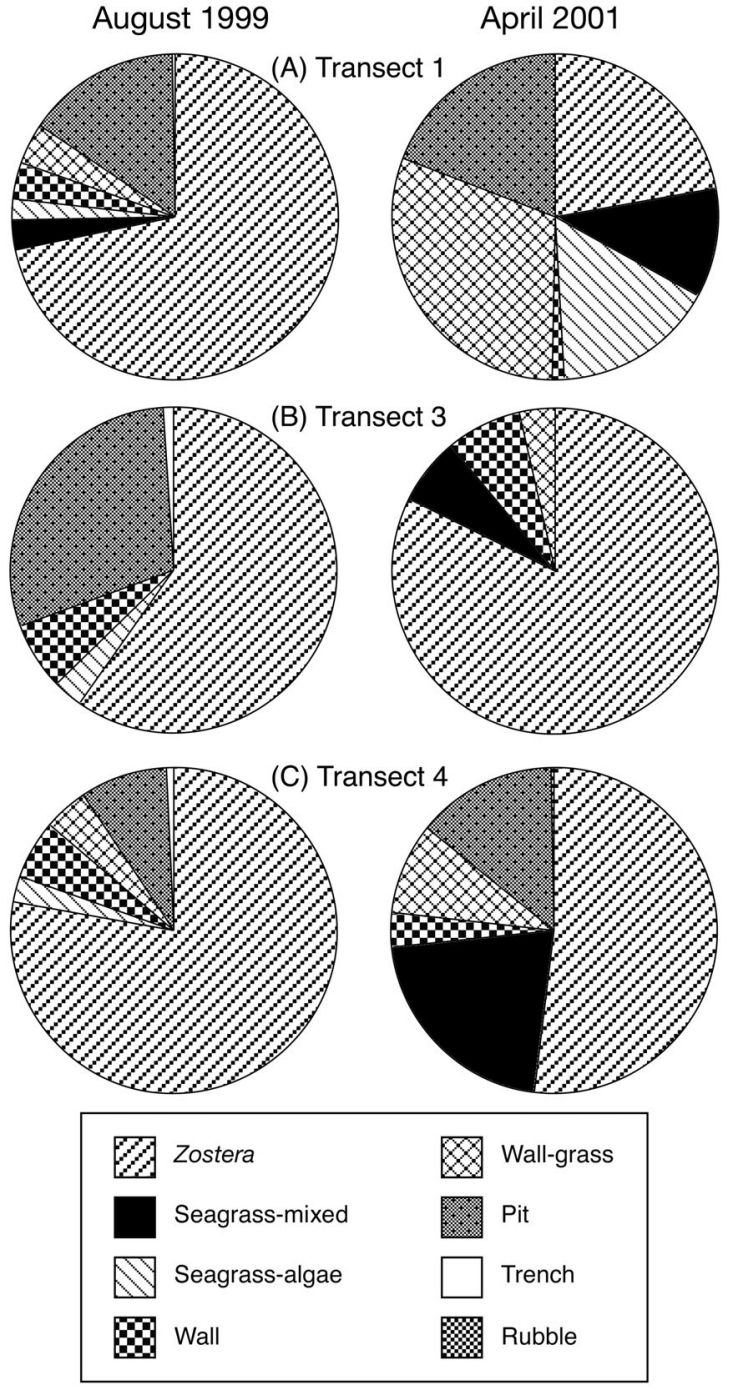

Fig. 2. General qualitative changes in the proportions of each type of substratum present at 3 (of 5) transects across Fisherman's Island in August 1999 and April 2001. See 'Results; Habitat composition; Qualitative changes' for sampling details

transect. The substratum surrounding commercial pits (i.e. walls, wall-seagrass, rubble, and trenches) was significantly more compacted than areas away from the pits (i.e. seagrass-Zostera, seagrass-mixed, and seagrass-algae) (Fig. 3). There were large quantities of shell material in the walls and associated habitat that formed a dense layer, often extending to a depth of 5 to $10 \mathrm{~cm}$. The seagrass-algae habitat was sometimes slightly more compacted than the other habitats containing seagrass. Sediment compaction in undug areas of pits was generally similar to unharvested areas of seagrass (i.e. outside the pits) (Fig. 3). These differences in compaction among the habitat types still persisted after 18 to 20 mo (April 2001), when the walls surrounding pits were still dominated by shell material that restricted penetration of the sediment (Fig. 3). 
August 1999

(A) Transect 1

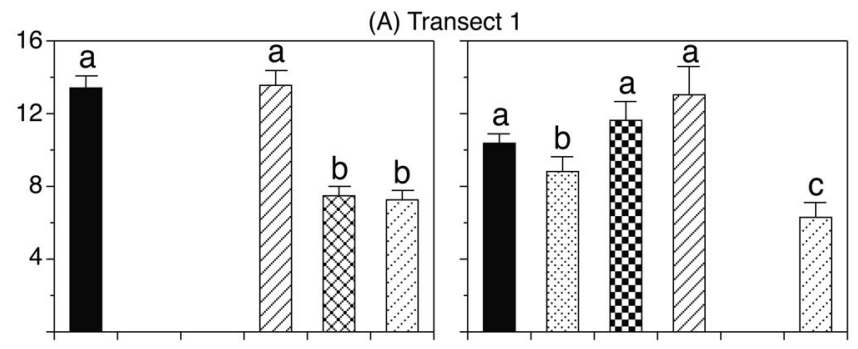

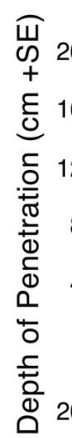
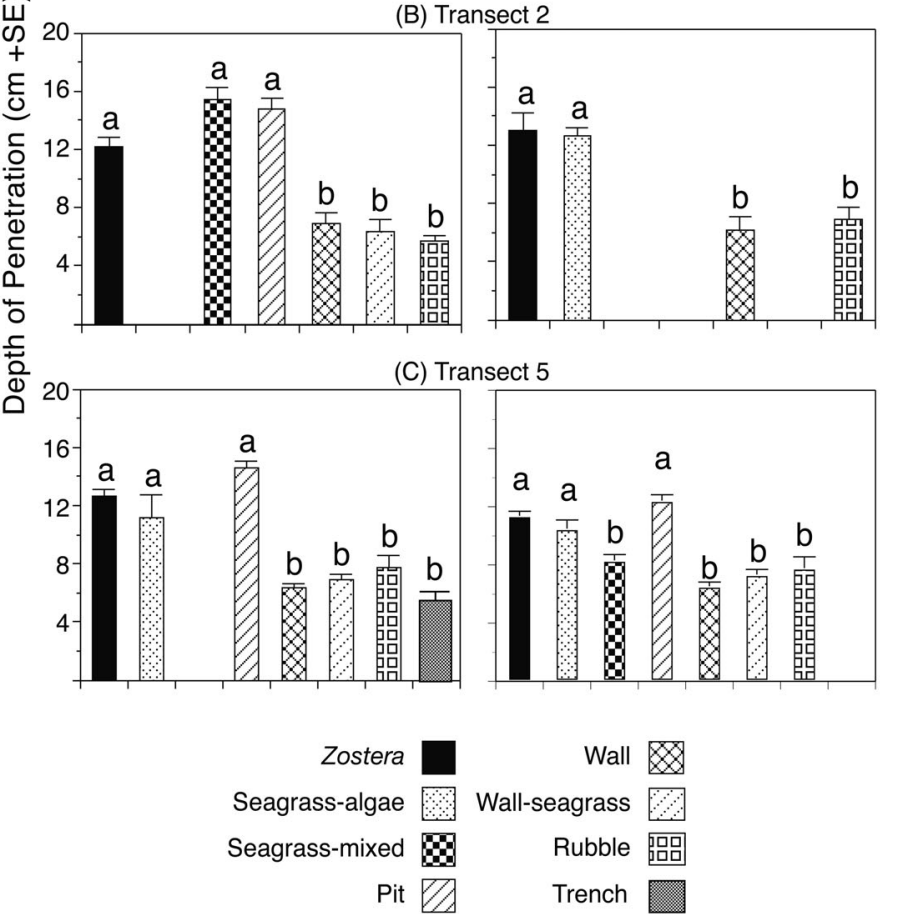

Fig. 3. Depth of penetration $(\mathrm{cm},+\mathrm{SE})$ into the substratum for different habitats along 3 (of 5) transects across Fisherman's Island in August 1999 and April 2001. Absence of a value for a habitat indicates that habitat was only present in a small proportion of the total transect, so measurements of compaction were not recorded. Letters above bars show results of Student-Newman-Keuls (SNK) post-hoc contrasts after 1-way ANOVA; means topped by the same letter were not significantly different $(\mathrm{p}>0.05)$

\section{Seagrass biomass}

In August 1999, the biomass of seagrass in the commercial pits was generally less than in nearby undug areas, although the magnitude of this varied among the 5 transects and depended on whether the measurement was for above- or below-ground biomass (Fig. 4). Areas with rubble and walls surrounding the pits generally had less seagrass than other types of habitat (Fig. 4), although sometimes these differences were not significant. Despite the 20 mo period that separated when transects were sampled, there was little

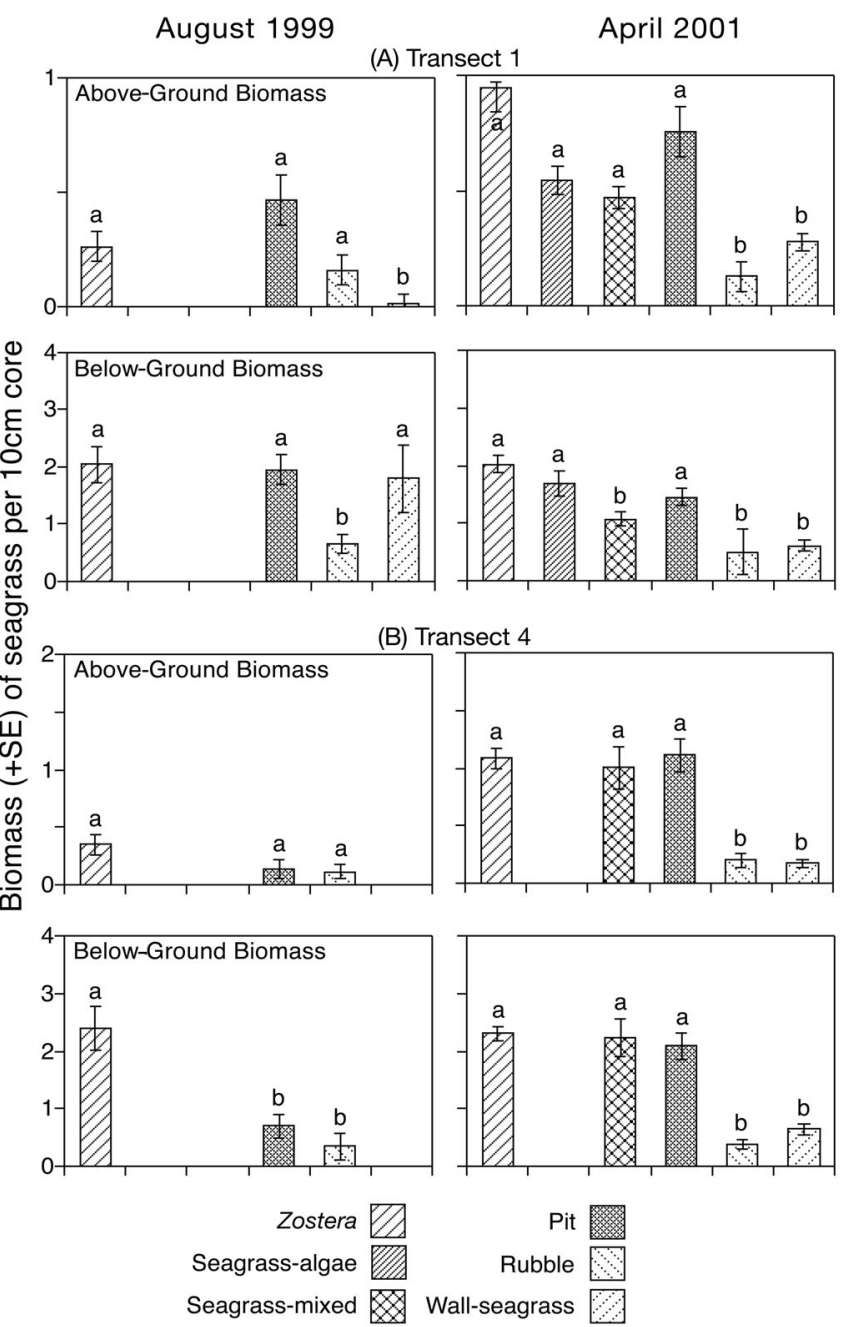

Fig. 4. Zostera capricorni, Halophila spp. and Halodule uninervis. Above- and below-ground biomass of seagrass for different habitats along 2 (of 5) transects across Fisherman's Island in August 1999 and April 2001. Other details as in Fig. 3. Note different scales along $y$-axes

change in the biomass of seagrass present in the rubble or on the walls; these areas continued to support significantly less seagrass than other habitats on all the transects (Fig. 4).

Between August 1999 and April 2001, there was a marked shift from Zostera capricorni dominated areas to areas with a mix of different species of seagrass (seagrass-mixed) and/or seagrass with macroalgae (seagrass-algae) along the transects (Fig. 2). Despite this qualitative change, there were no marked changes in the biomass of seagrass present in these areas. Where there was a change to seagrass-algae dominated areas, the additional plant material from the algae caused an overall increase in the biomass of above-ground vegetation but no change in the biomass of seagrass. 


\section{Changes to commercial pits}

The average $( \pm \mathrm{SE})$ area of the pits crossed by the transects was $85.1 \mathrm{~m}^{2}( \pm 5.5 ; \mathrm{n}=30)$ in August 1999 and $74.4 \mathrm{~m}^{2}( \pm 6.4 ; \mathrm{n}=18)$ in April 2001. The size of the pits was similar among the different transects, and the difference in the size of the pits did not differ significantly between the 2 periods (ANOVA, $p>0.05$ ).

The height of the walls around the commercial pits was similar across the 5 transects, except for along Transect 1, where the walls were slightly smaller (Fig. 5). There was also a significant (but only a few $\mathrm{mm}$ ) difference in the height of the outside and inside margins of the walls. Between August 1999 and April 2001 the walls collapsed and merged with the surrounding substratum. Data are not shown for Transect 3 (Fig. 5) because no walls were evident along this transect in April 2001 (i.e. they had completely merged with the surrounding area). The number of breaches in the pits ranged from 0 to 5 , with the greatest proportion (39\%) having 2 holes present. Eighteen percent of the pits along the transects were not breached at all, effectively forming pools during low tide by trapping water and not flooding until the tidal height was greater than the height of the walls.

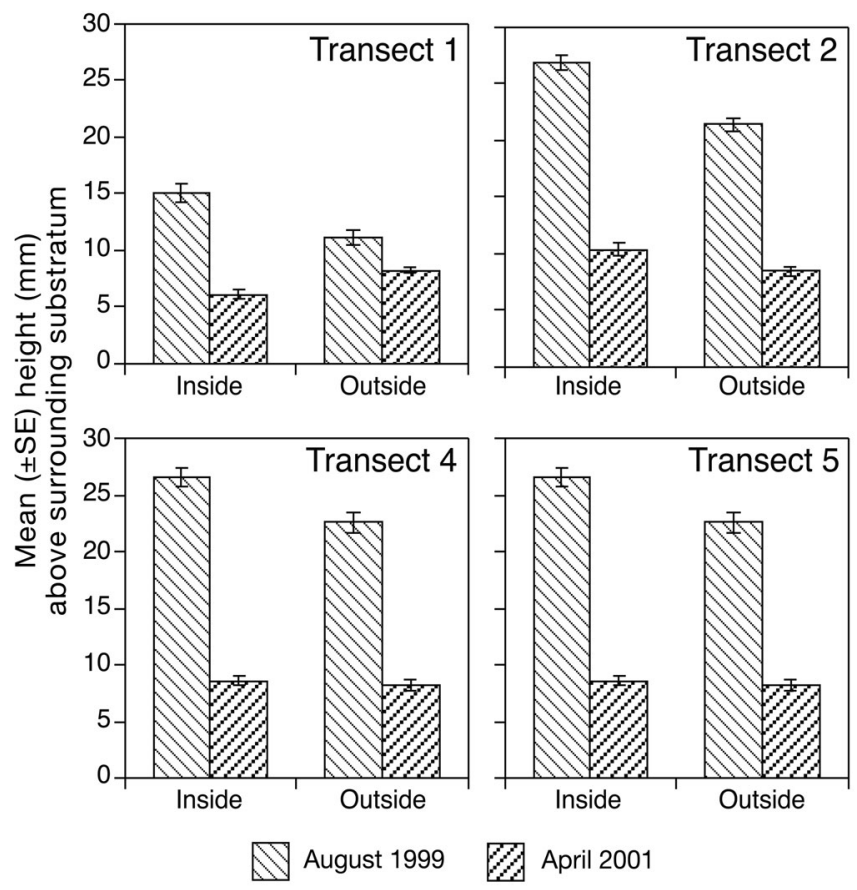

Fig. 5. Heights of walls surrounding commercial pits along transects across Fisherman's Island. Data are mean of 5 readings along each of the 4 walls per pit in August 1999 and April 2001. Transect 3 not shown: no pits were evident along this transect in April 2001. Inside and outside refer to the inner and outer edge of the walls, which tended to slope gently away from the pit

\section{Infauna and commercial pits}

$$
1 \text { mo old pits }
$$

There were generally fewer animals in and around the commercial pits than in surrounding undug areas (internal and external reference area), but the magnitude of these differences varied considerably among the different taxa and also between the 2 commercial pits that were examined. For example, the number of gammarid amphipods from locations around the pit was less than those in the external reference areas by 39 to $71 \%$ inside the commercial pits, 23 to $57 \%$ on the walls and 16 to $42 \%$ outside the pit (Fig. 6A). The abundance of polychaetes (Fig. 6B) mirrored those for gammarids in that significantly fewer animals were present in and around the commercial pits than in undug areas. In contrast, the abundance of gastropods (Fig. 6C), bivalves and ophiuroids (not shown) in and around the commercial pits did not differ significantly from the reference areas. There were no significant differences in the abundance of any taxa between the internal and external reference areas.

\section{2 mo old pits}

The differences in the abundance of infauna in the habitats in and around the commercial pits and the undug area after 2 mo were similar to those for 1 mo old pits. The total number of infaunal animals was 78 to $81 \%$ less inside the pits, 60 to $82 \%$ less on the walls and 63 to $78 \%$ less outside the pits compared with the external reference areas. The differences between the 2 commercial pits were less at 2 mo than at 1 mo after construction. Again, there were significantly fewer (53 to $100 \%$ ) gammarid amphipods (Fig. 7A) and polychaetes (Fig. 7B) in and around the pits than the undug areas. The differences for gastropods (Fig. 7C) and bivalves (not shown) were by 2 mo clearly defined, with significantly fewer animals present in at least some of the habitats associated with the pits than the undug areas. Again, there was little indication of any differences in the abundance of infauna between the internal and external reference areas.

\section{4 mo old pits}

There were few indications of significant recovery of infauna within the commercial pits and on the walls 4 mo after the pits had been dug, although there were now fewer significant differences in the abundances of animals in the area outside the pits compared with the 


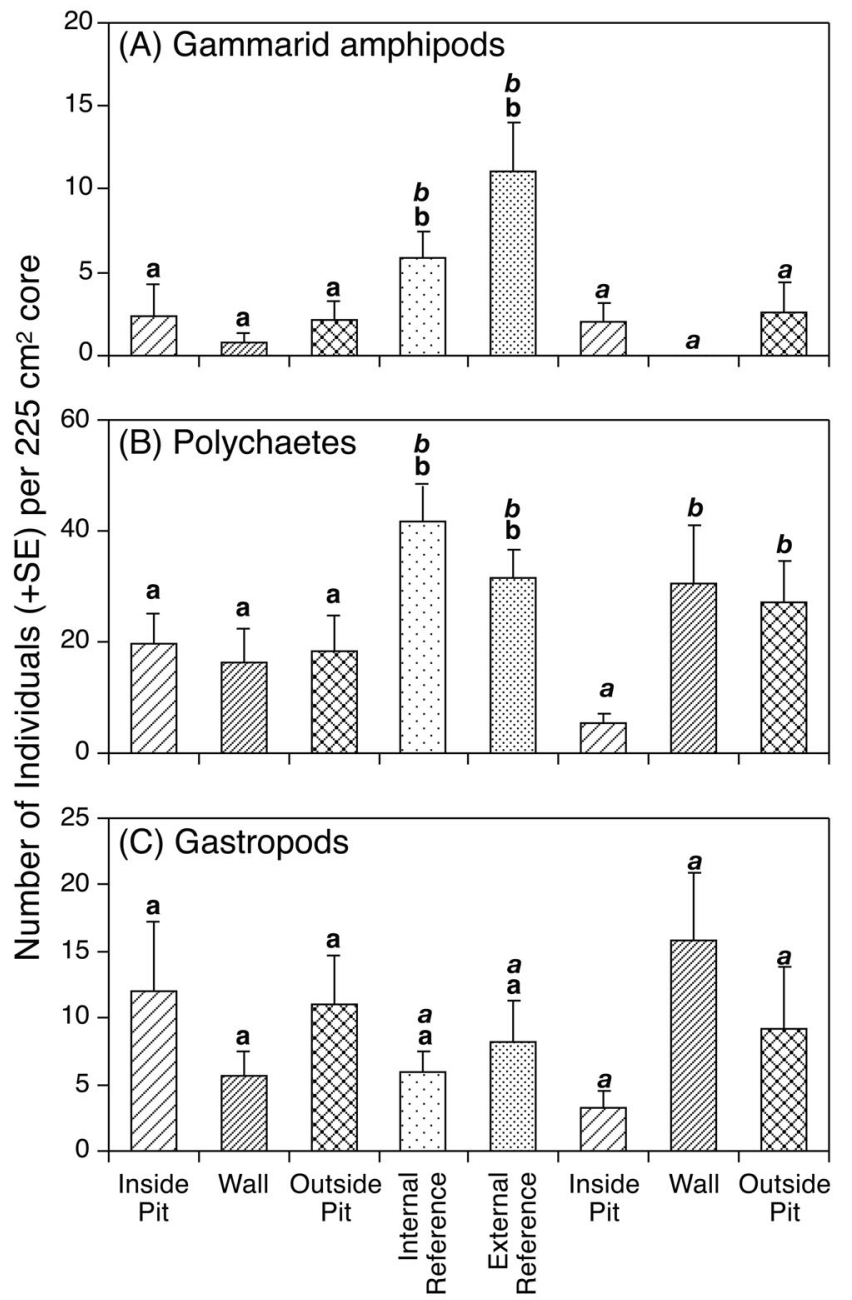

Fig. 6. Mean (+SE) abundance of (A) gammarid amphipods, (B) polychaetes, and (C) gastropods in $225 \mathrm{~cm}^{2}$ cores collected from in and around commercial bloodworm pits dug $1 \mathrm{mo}$ earlier. Five habitats were sampled: (1) Inside Pit, inside the commercial pit; (2) Wall, the walls (dyke) surrounding the pit; (3) Outside Pit, area immediately outside (10 to $15 \mathrm{~cm}$ ) external wall; (4) Internal Reference, undug area within the commercial plot; (5) Outside Reference, undug area away from commercial plot. $\mathrm{N}=5$ replicates for Habitats $1-3 ; \mathrm{N}=10$ replicates (pooled from 2 areas) for Habitats 4-5 (see 'Infauna and commercial pits' for further details). Letters above bars show results of SNK post-hoc contrasts after ANOVA: means topped by the same letter were not significantly different $(p>0.05)$. Analyses were done separately for each of the 2 pits: italicised letters indicate a separate set of contrasts from the plain letters. Note different scales along $y$-axes

undug reference areas. The total abundance of infauna was 70 to $72 \%$ less inside the pits, 46 to $72 \%$ less on the walls and 35 to $45 \%$ less outside the pits compared with the external reference areas.

There were 83 to $97 \%$ fewer gammarid amphipods (Fig. 8A), 70 to $86 \%$ fewer bivalves (Fig. 8B) and 69 to $94 \%$ fewer nereidid polychaetes (Fig. 8C) in dug areas

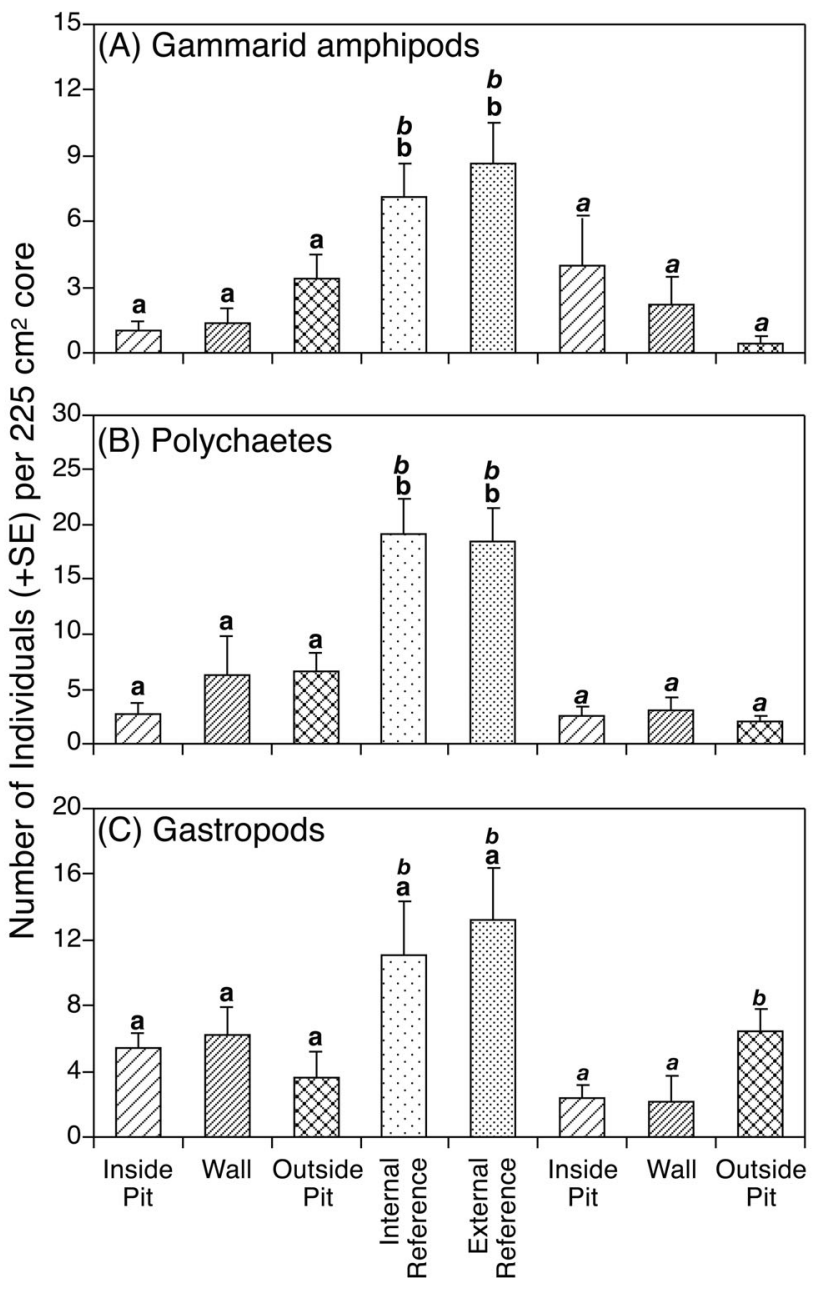

Fig. 7. Mean (+SE) abundance of (A) gammarid amphipods, (B) polychaetes, and (C) gastropods in $225 \mathrm{~cm}^{2}$ cores collected from in and around commercial bloodworm pits dug 2 mo earlier. Other details as in Fig. 6

of the commercial pits (inside, walls and outside) than the external reference areas, but there were no significant differences present among the various types of dug habitat. In contrast, for groups such as tanaid crustaceans (Fig. 8D), gastropods (Fig. 8E), spionid polychaetes (Fig. 8F) and syllid polychaetes (not shown), only some habitat types (usually the inside and the wall) had fewer animals than in the external reference areas, and there were large differences between the 2 commercial pits.

\section{2 mo old pits}

Only 862 animals were recovered from 80 samples (48 in and around pits, 32 from external reference areas), compared with 1417 animals from 50 samples collected after 2 mo potential recovery. More impor- 

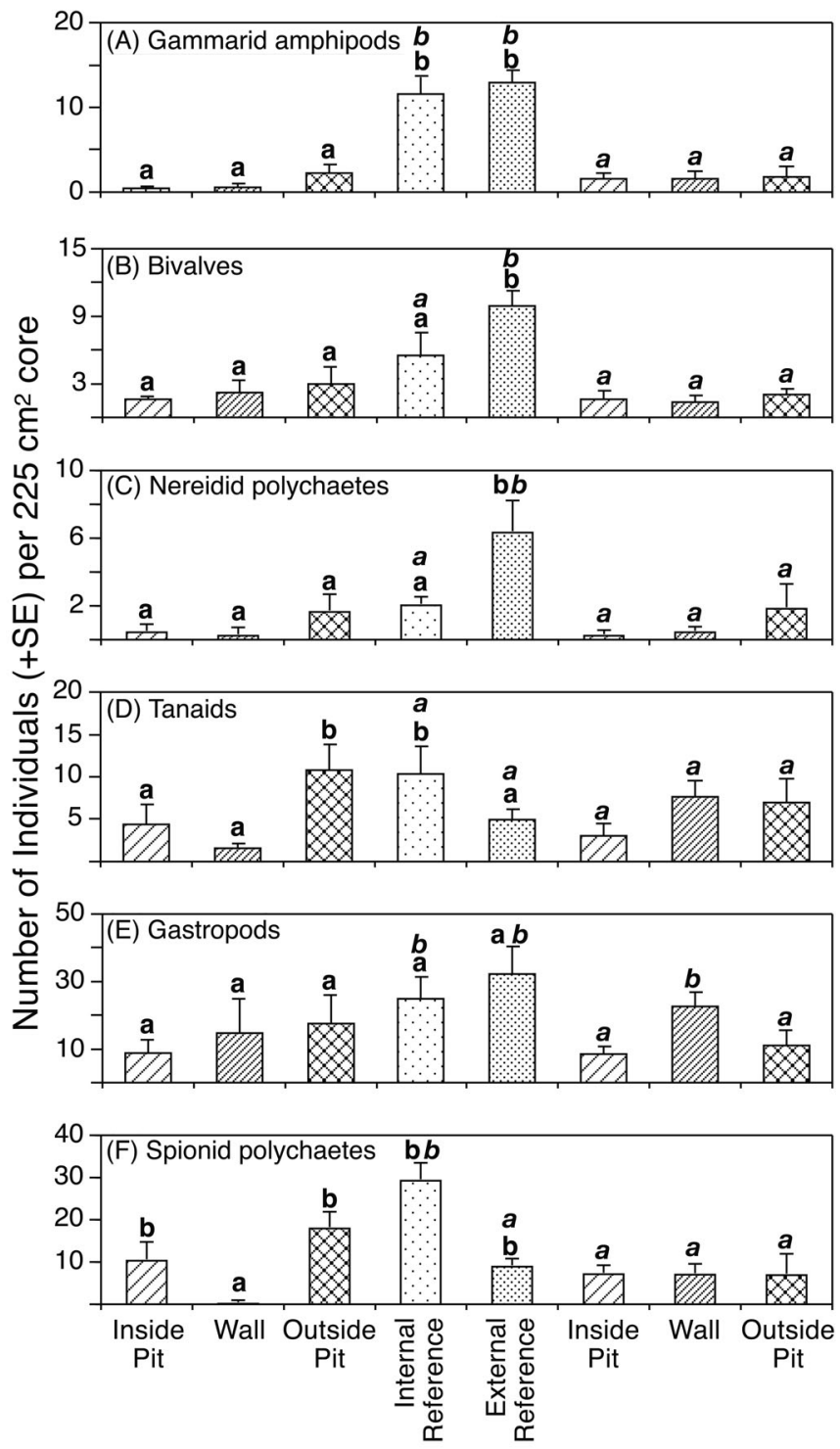

Fig. 8. Mean (+SE) abundance of (A) gammarid amphipods, (B) bivalves, (C) nereidid polychaetes, (D) tanaids, (E) gastropods, and (F) spionid polychaetes in $225 \mathrm{~cm}^{2}$ cores collected from in and around commercial bloodworm pits dug 4 mo earlier. Other details as in Fig. 6

tantly, the data collected in and around the commercial pits after 12 mo recovery were characterised by substantial variation, with many samples having no or few animals present and many taxa only occurring at a few of the 8 external reference areas. This was most noticeable for groups such as the crustaceans (Fig. 9A), polychaetes (Fig. 9B) and gastropods (Fig. 9C), which had been relatively abundant and widely distributed during previous periods of sampling. No significant differences in the abundance of any taxa were detected among any of the habitats in and around the commercial pits and the external reference areas. There were no significant differences in the composition of the benthic assemblage in and around any of the 4 commercial pits and the external references areas.

\section{Epibenthos and commercial pits}

\section{Commercial Area 1}

There was no indication that the abundance of epibenthic animals was affected by the presence of the commercial pits in the main commercial area on Fisherman's Island. There was considerable variation in the abundance of all fauna among the different pits, but also among the different reference sites that were sampled; this resulted in a significant site-effect in all analyses (ANOVA, Site[Habitat]) but no significant effect for Habitat. For some taxa, on average there were more animals present in the pits than in reference areas (e.g. hermit crabs, Fig. 10A; mud whelks Pyrazus ebeninus, Fig. 10B), but these differences were not significant and were usually the result of 1 or a few pits having very large numbers present. The converse situation was also observed, with on average more of some taxa in the reference sites than around the commercial pits (e.g. oyster drills Bedeva paivae, Fig. 10C; Nassarius burchardi, Fig. 10C).

\section{Commercial Area 4}

A similar pattern was evident around the commercial pits at the other end of Fisherman's Island (Fig. 10E-H), with the exception that there were significantly more hermit crabs (primarily Clibanarius taeniatus) around the commercial pits than in the reference sites (Fig. 10E). This result was, however, primarily a function of the large numbers present at a single commercial pit. For species such as Batillaria australis (Fig. 10F), Bedeva paivae (Fig. 10G), Nassarius burchardi (Fig. 10H) and Thalotia marginata (not shown), there was significant variation in the abundance of taxa among the different commercial pits and/or references sites, but no overall significant difference between the 2 treatments.

\section{Wynnum-Manly (recreational harvest area)}

The same species observed in the commercial areas dominated the epibenthos in the seagrass of the recreational harvesting area (i.e. Bedeva paivae, Pyrazus ebeninus, Thalotia marginata, Nassarius burchardi). Again, there was significant variation among the individual pits and reference sites for each of these taxa, but there was no significant difference between the 2 treatments. 


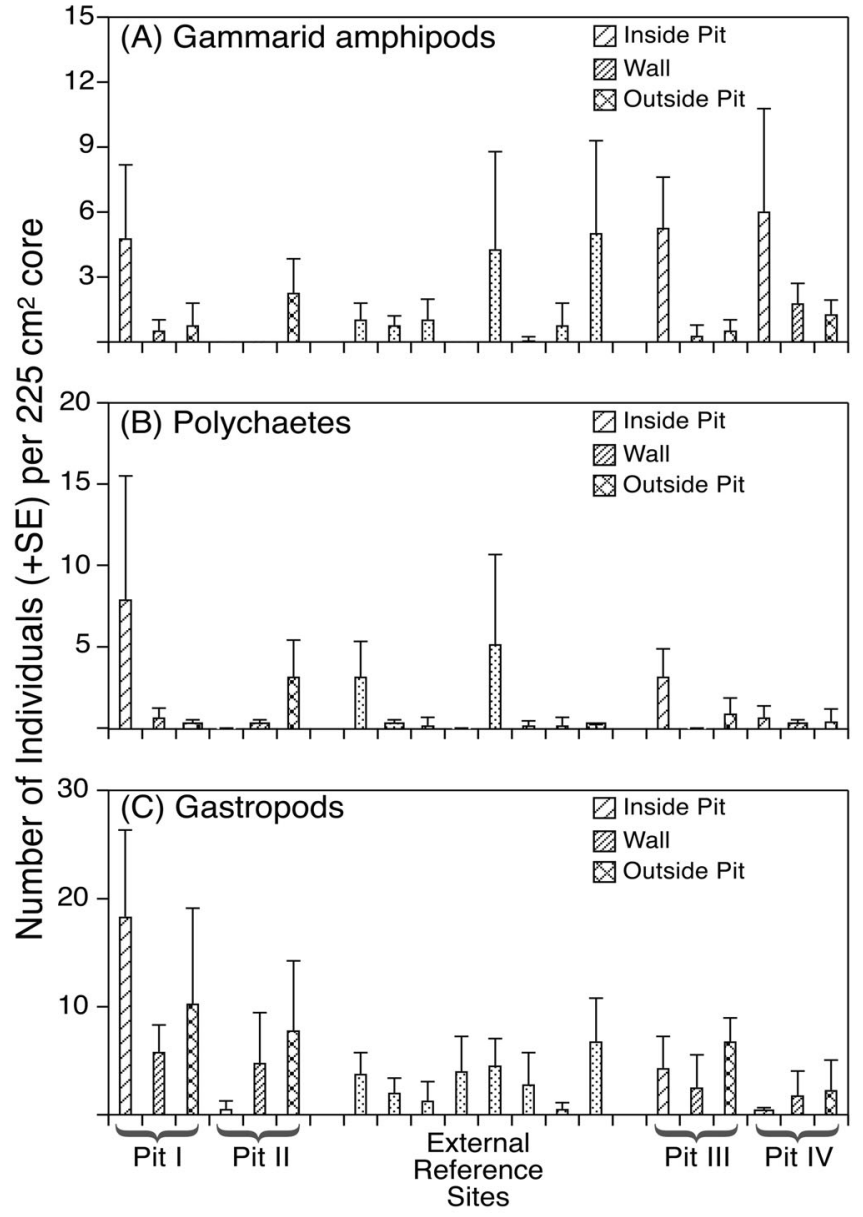

Fig. 9. Mean (+SE) abundance of (A) gammarid amphipods, (B) polychaetes, and (C) gastropods in $225 \mathrm{~cm}^{2}$ cores collected from in and around commercial bloodworm pits dug $12 \mathrm{mo}$ earlier. $\mathrm{N}=4$ replicates for all habitats. Other details as in

Fig. 6 (note: Internal Reference not sampled)

\section{Assemblage composition}

There were no significant differences in the composition of the epibenthic assemblages around the pits and among reference sites at either of the commercial plots or in the Wynnum-Manly recreational harvest area (ANOSIM and nMDS: Fig. 11). As for the individual taxa, there was significant variation in the composition of the epibenthic assemblage among the different sites examined (ANOSIM).

\section{Effects of experimental disturbance on epibenthos}

\section{North Stradbroke Island}

There was no consistent, significant effect of physical disturbance on the above-ground biomass of seagrass at the sites on North Stradbroke Island (Fig. 12A).
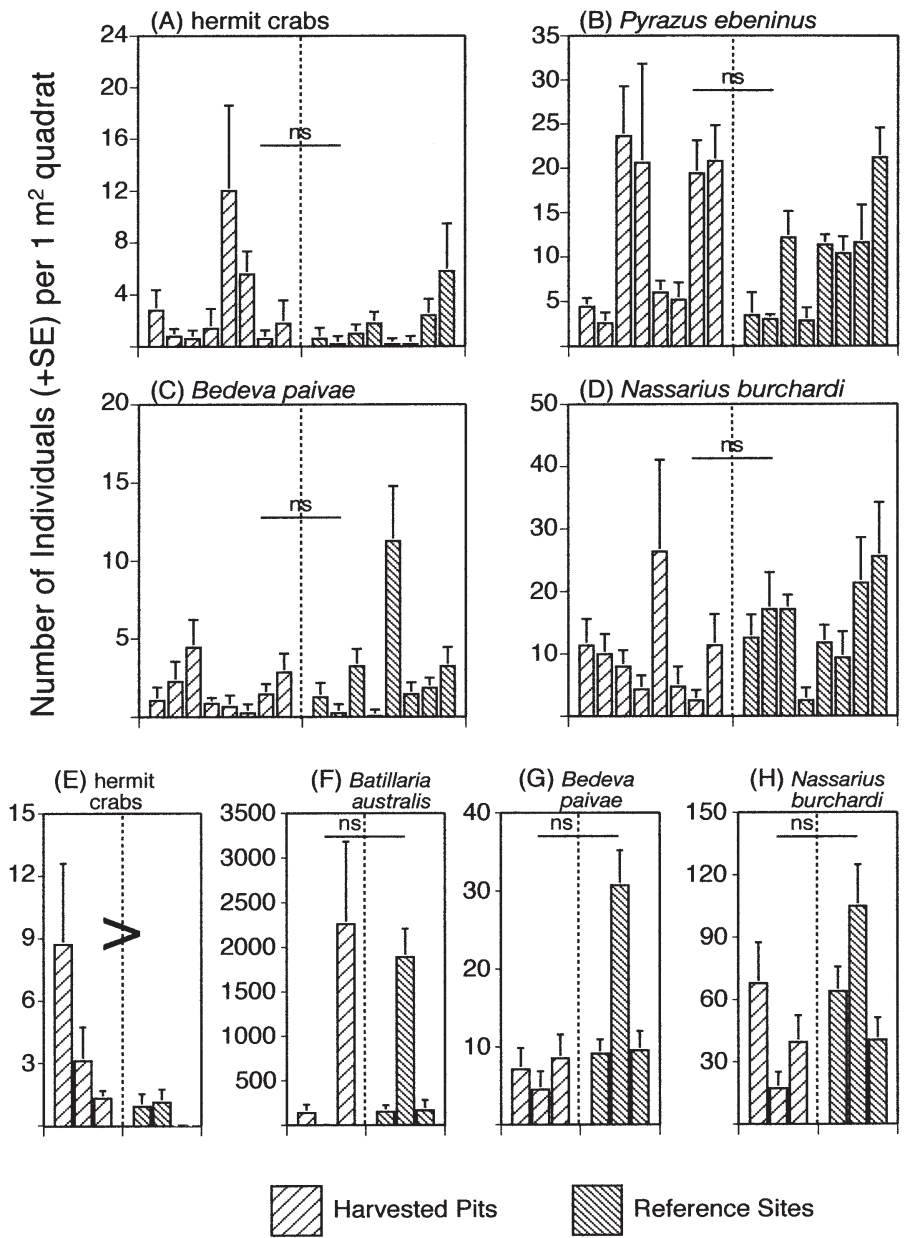

Reference Sites

Fig. 10. Mean (+SE) abundance of animals in $1.0 \mathrm{~m}^{2}$ quadrats collected from the seagrass adjacent to bloodworm harvesting pits and in reference sites. Commercial Area 1: (A) hermit crabs, (B) Pyrazus ebeninus, (C) Bedeva paivae, and (D) Nassarius burchardi. Commercial Area 4: (E) hermit crabs, (F) Batillaria australis, (G) Bedeva paivae, and $(\mathrm{H})$ Nassarius burchardi. $\mathrm{N}=5$ for each of the pits and reference sites; ns: no significant difference $(p>0.05)$ between treatments in 2-factor ANOVA; $>$ : significant difference $(p<0.05)$ between treatments. See text for further details. Note different scales along $y$-axes

There was a significant Site $\times$ Time interaction $(\mathrm{p}<$ 0.02 ), a result of the greater decrease in average biomass between 8 and 21 wk at Site 2 compared with Site 1 . None of the terms involving the disturbance treatments were significant. There was a trend towards decreased biomass of seagrass in the High Disturbance (HD) treatment than in the Low Disturbance (LD) treatment after $8 \mathrm{wk}\left(\bar{x}_{\mathrm{HD}} \pm \mathrm{SE}=0.46 \pm 0.06 \mathrm{~g}_{;} \bar{x}_{\mathrm{LD}}\right.$ $\pm \mathrm{SE}=0.68 \pm 0.04 g_{i} \bar{x}_{\mathrm{CTL}} \pm \mathrm{SE}=0.61 \pm 0.06 ; 28.7 \%$ decrease) but not at $21 \mathrm{wk}\left(\bar{x}_{\mathrm{HD}} \pm \mathrm{SE}=0.58 \pm 0.04 \mathrm{~g} ; \bar{x}_{\mathrm{LD}}\right.$ $\left.\pm \mathrm{SE}=0.57 \pm 0.08 \mathrm{~g} ; \bar{x}_{\mathrm{CTL}} \pm \mathrm{SE}=0.56 \pm 0.04\right)$ but the Time $\times$ Disturbance interaction was not significant (ANOVA, p > 0.08) suggesting low power in that test. 

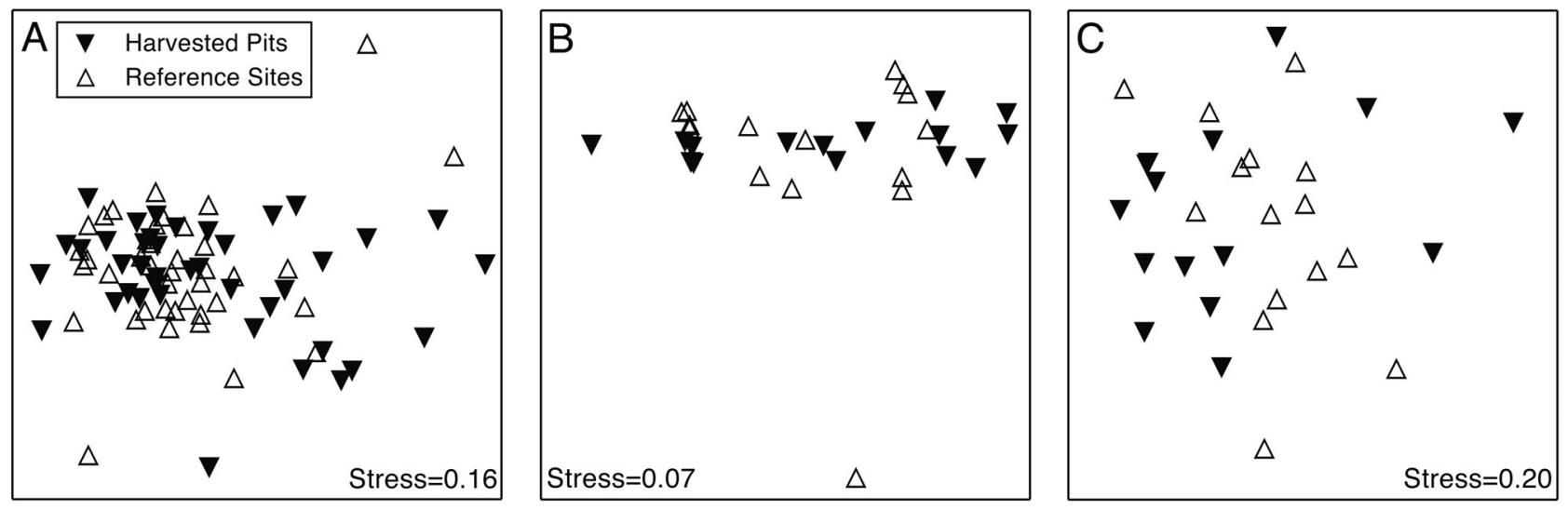

Fig. 11. nMDS ordinations of untransformed data on abundances of epibenthic macrofauna from the seagrass adjacent to commercial and recreational pits and in reference sites near (A) Commercial Area 1, (B) Commercial Area 4, and (C) Wynnum-Manly recreational digging area. $\mathrm{N}=5$ replicate $1 \mathrm{~m}^{2}$ quadrats for each site (pit or reference area) sampled

(A) Above-ground biomass

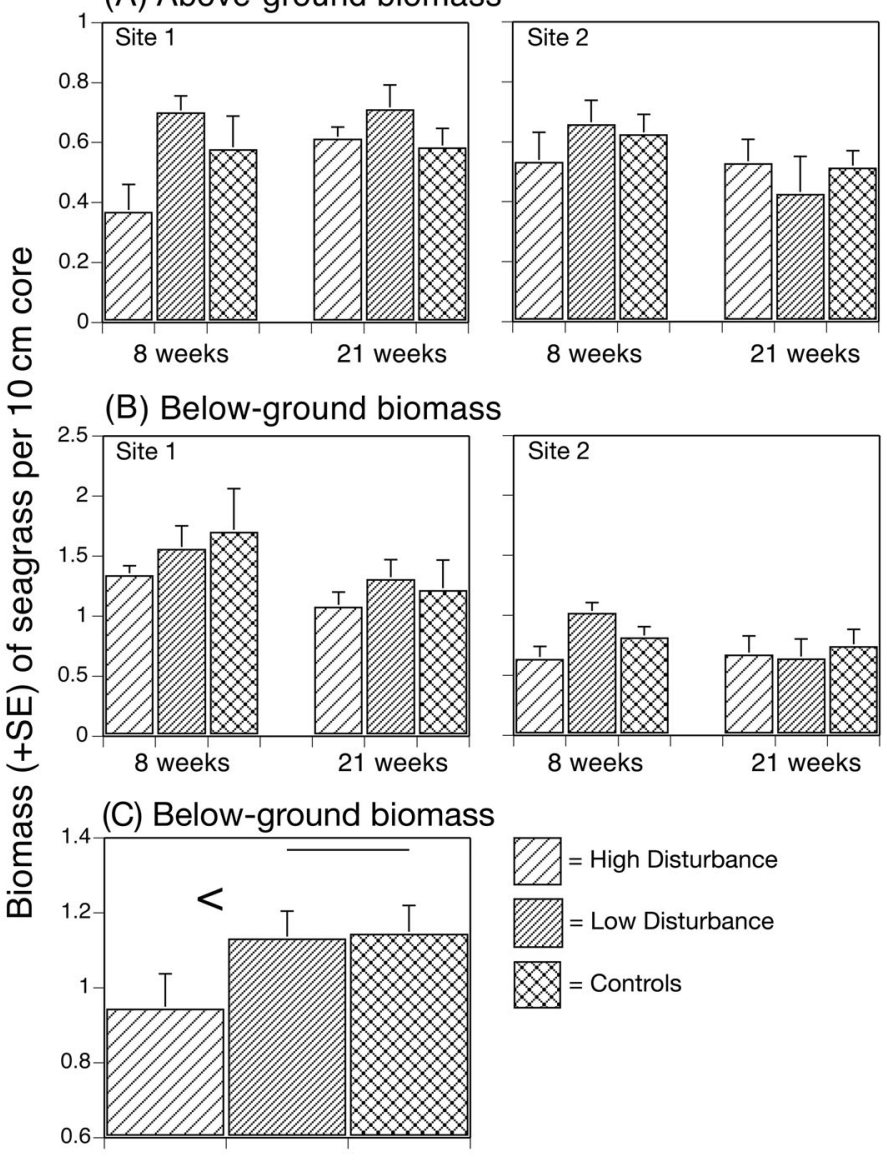

Fig. 12. Zostera capricorni. Mean (+SE) biomass of (A) aboveground and (B) below-ground seagrass in $1 \mathrm{~m}^{2}$ patches of intertidal habitat at 3 levels of disturbance (High, Low and Control) sampled 8 and $21 \mathrm{wk}$ after start of the experiment at 2 sites on North Stradbroke Island; (B) shows differences between the 2 sites at each time, (C) shows the differences among the 3 treatments. $\mathrm{N}=4$ replicates for each treatment; $<$ significant difference among treatments $(\mathrm{p}<0.05)$ from SNK tests after ANOVA
The biomass of below-ground seagrass (roots and rhizomes) varied significantly between sites (ANOVA, $\mathrm{p}<0.001$; Fig. 12B) and among disturbance levels ( $p<0.006$; Fig. 12C). There was a $17 \%$ decline in below-ground seagrass in the High Disturbance treatment compared with the other 2 treatments over the course of the experiment.

Despite the loss of seagrass in the High Disturbance patches, there was no significant effect of disturbance on any of the epibenthic taxa at 8 or $21 \mathrm{wk}$ after the start of the experiment (Fig. 13). Numbers of individuals of the different taxa were generally very consistent among treatments and between the 2 sites (e.g. Nassarius burchardi, Fig. 13B; Thalotia marginata, Fig. 13C), although there were occasionally significant differences between the 2 sample times (e.g. Clanculus spp., Time: $\mathrm{p}<0.05$, Fig. 13A; nereid polychaetes, Time: $\mathrm{p}<0.05$, Fig. 13D; amphipods, Time: $\mathrm{p}<$ 0.05, Fig. 13E). There was no significant effect of disturbance as an interaction (with Time or Site) or main effect for any taxon examined.

\section{Fisherman's Island}

In contrast to the results on North Stradbroke Island, physical disturbance had no detectable influence on the biomass of seagrass on Fisherman's Island (ANOVA: Fig. 14) after 8 wk. There were no significant effects on the abundance of any of the epibenthic animals in the seagrass at Fisherman's Island with the exception of brittle stars (ophiuroids). Where there was a difference in abundance between the High Disturbance and Control patches at one site, the other site usually showed the opposite pattern (e.g. Batillaria australis, Smaradgia souverbiana, Ilyograpsus paludicola). The abundance of brittle stars was significantly 


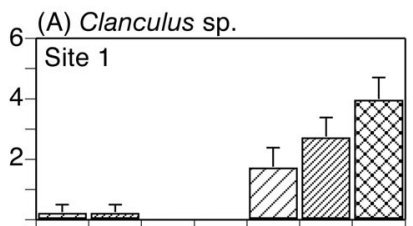

8 weeks

21 weeks
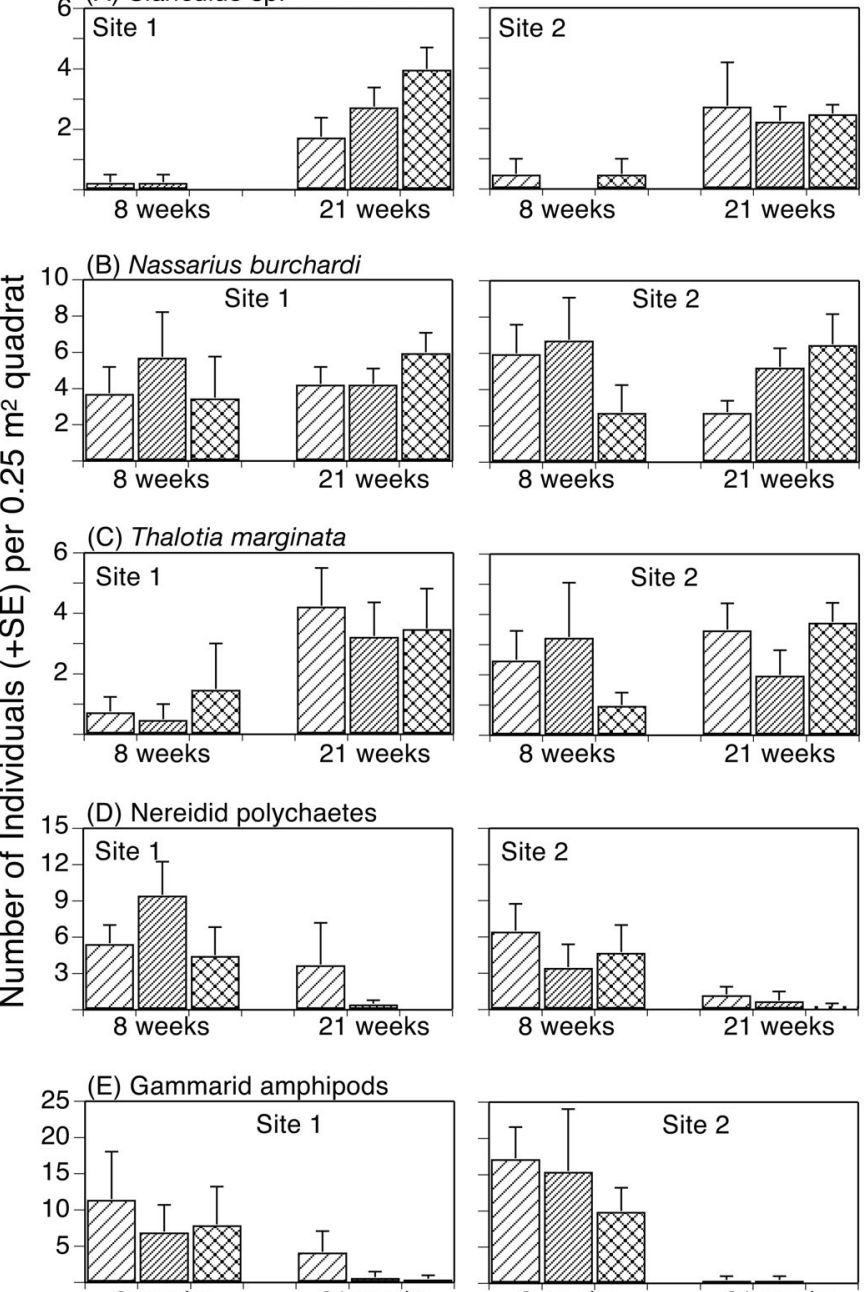

8 weeks 21 weeks

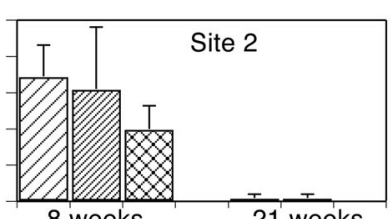

8 weeks

21 weeks

$27=$ High Disturbance

$=$ Low Disturbance

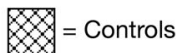

Fig. 13. Mean (+SE) number of (A) Clanculus sp., (B) Nassarius burchardi, (C) Thalotia marginata, (D) nereidid polychaetes, and (E) gammarid amphipods in $1 \mathrm{~m}^{2}$ patches of intertidal Zostera capricorni habitat at 3 levels of disturbance (High, Low and Control) sampled 8 and 21 wk after start of the experiment at 2 sites on North Stradbroke Island. $\mathrm{N}=4$ replicates for each treatment. Note different scales along $y$-axes

greater in the High Disturbance than Control patches at one site, but the opposite pattern occurred at the 2nd site (Disturbance $\times$ Site interaction, $\mathrm{p}<0.01$ )

\section{DISCUSSION}

Harvesting of bloodworms by commercial operators on Fisherman's Island was associated with a significant decline in seagrass (above- and below-ground), increased compaction of the sediments, and changes to the topography of the area. The primary technique

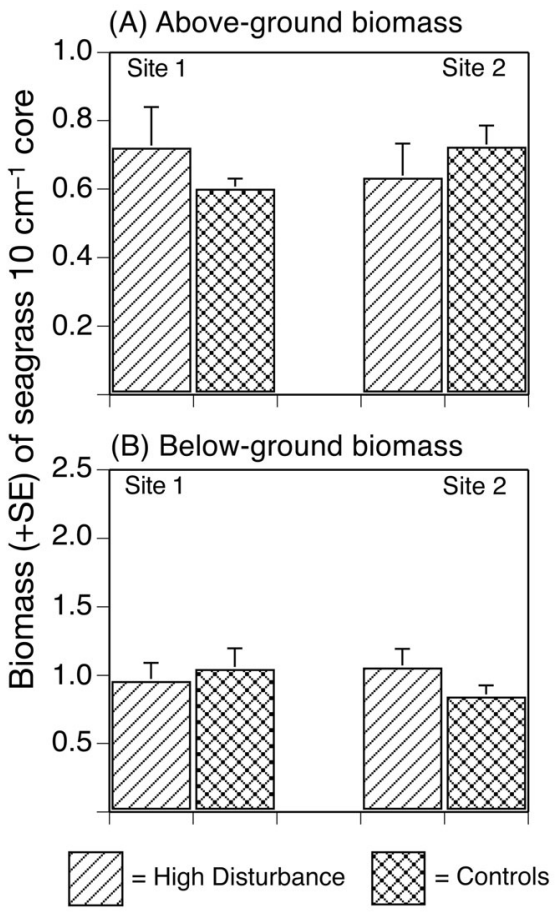

Fig. 14. Zostera capricorni. Mean (+SE) biomass of (A) aboveground and (B) below-ground seagrass in $1 \mathrm{~m}^{2}$ patches of intertidal habitat at 2 levels of disturbance (High and Control) sampled $8 \mathrm{wk}$ after start of the experiment at 2 sites on Fisherman's Island. $\mathrm{N}=4$ replicates for each treatment

used by commercial operators on Fisherman's Island is the bail-and-dyke technique (Forbes 1984, WBM Oceanics 1993). A raised wall (dyke) is built from the substratum, surrounding an area of seagrass from which the bloodworms will be dug. Water is bailed from inside the dyke with either buckets or, in some cases, using petrol-driven hydraulic pumps. During this process, buried shell material and rubble is brought to the surface and piled onto the walls of the dyke. This shell and rubble often forms an almost impenetrable layer on or just below the substratum, significantly increasing the overall compaction of these areas. Even after 18 to $20 \mathrm{mo}$, the walls and areas of rubble surrounding the pits were still significantly more compacted than other habitats along the transects, presumably because the large fragments of shell and rubble remain close to the surface and are only slowly buried in this relatively low energy physical environment.

The presence of a shell layer near the surface of the substratum may prevent burrowing animals from obtaining an important refuge from predation through burial (Hines \& Comtois 1985, Barshaw \& Able 1990). This would account for the small abundances of infauna in the wall, even after 4 mo recovery. The only animals that were significantly more abundant in the walls than 
surrounding habitats were hermit crabs (primarily Clibanarius taeniatus) that were presumably responding to the increased availability of shells available for occupation (Abrams 1980, Abrams et al. 1986).

During digging, considerable amounts of fine sediment are deposited in the commercial pits and the water that is bailed from the pits to facilitate digging is usually heavy with suspended sediments. This material is resuspended as the tide rises (authors' pers. obs.) but will eventually be deposited back onto the substratum and potentially bury animals left in the pits, or those attempting to colonise any remaining seagrass. Direct burial of organisms due to sedimentation is a potential impact arising from digging of the pits, especially when there is inadequate attention paid to restricting the extent of transport of the resuspended material (Maurer et al. 1981a,b, 1982). There are currently no mechanisms in place as part of commercial operations to restrict this and it would be practically very difficult to establish such mechanisms given the nature of the fishery. Organisms that are attached to hard substrata (e.g. oysters, mussels and barnacles) are likely to be killed outright when smothered by fine sediments because of their inability to burrow above the deposited material (Saila et al. 1972, Carriker 1986). This may include the numerous animals that live on seagrass blades (Keough 1986, Ward 1989, Dirnberger 1994). Burial under sediments may not be an issue for animals outside the pits because of the slow accumulation of fine sediments settling back onto the substratum, potentially allowing animals time to adjust their vertical position in the sediment. Burial may be a more significant problem for animals inside the pits, some of which are greater than $1 \mathrm{~m}$ deep, where animals are buried beneath substantial amounts of fine sediment.

While most field-based experimental studies dealing with the effects of disturbance of sediments on softsediment communities have been primarily interested in rates of recovery and the successional sequence involved in recolonisation (reviewed by Thistle 1981), some studies have examined the effects of smothering on infauna (Rhoads 1974). Brenchley (1981), for example, found that the impact of burial on infauna depended on the mobility of the animals (tubedwellers vs. mobile burrowers) and their feeding type (suspension-feeders vs. deposit-feeders). Similarly, Peterson (1985) found that suspension-feeding clams were more susceptible to mortality from burial than deposit-feeding clams. None of these studies specifically examined the effects of smothering from continuously deposited sediments on the survival of new recruits.

The potential effect of rubble and shell material in hindering burial of infauna and reducing diversity and abundance may be counteracted by enhanced stability of the sediments provided by the additional structure. Animal tubes (Rhoads \& Young 1971, Woodin 1979) and seagrass (e.g. Ginsburg \& Lowenstam 1958, den Hartog 1977, Fonseca et al. 1983, Fonseca 1989) stabilise sediments, with an associated increase in species richness and abundance of animals. Rubble may have a similar stabilising effect and has also been shown to enhance the settlement and recruitment of some crabs (e.g. Arnold 1984, Dumbauld et al. 1993) and bivalves (Skilleter 1994) through the provision of enhanced refuges from predation.

The shift from an intertidal area dominated by Zostera capricorni to one with a mixture of Z. capricorni, Halophila spp. and Halodule uninervis in response to physical disturbance is not surprising, given results of past research on the factors determining species diversity in seagrass meadows (e.g. den Hartog 1977, Clarke \& Kirkman 1989, Duarte et al. 1997). Genera such as Halophila and Halodule maintain a small total biomass but are often able to recover rapidly after disturbances, especially those associated with sedimentation (Duarte et al. 1997). Halophila ovalis in particular has been shown to recover from burial within a few months (Brouns 1987, Clarke \& Kirkman 1989, Duarte et al. 1997). Despite the qualitative change in the composition of the seagrasses, $Z$. capricorni was still the dominant species of seagrass along the transects and the biomass of the other species (primarily $H$. uninervis and $H$. ovalis) was always relatively small. The maintenance of the biomass of $Z$. capricorni (and the total biomass of seagrass), especially the below-ground component, suggests that any indirect changes from commercial bait-harvesting on the benthic fauna may be relatively minor.

The intact root and rhizome mat may be important in subsequent recolonisation and recovery of the dug areas. Recolonisation of seagrass is often via clonal growth into gaps created by a disturbance (SandJensen 1975, Vermaat et al. 1995, Creed \& Amado Filho 1999, Rasheed 1999). The walls and rubble banks around the pits had a relatively small biomass of seagrass even after 18 to 20 mo of recovery, suggesting that the compacted sediment (with the large proportion of shell material) may hinder lateral growth of the seagrass from the surrounding undug areas. If this is the case, then recolonisation of the dug sections of each pit may be heavily dependent upon the remaining undug portion, or the creation of sufficient gaps in the walls after the pit has been harvested. Commercial harvesters indicated that they left a portion of each pit undug in order to facilitate recolonisation of the dug areas; the seagrass in these sections had a similar above- and below-ground biomass to other parts of the transect and would likely provide good opportunities 
for subsequent recolonisation of the dug areas once the sediment had stabilised. Similarly, many operators deliberately opened gaps into the walls because of the belief that it enhanced recovery of seagrass in the pits.

The walls of the pits and associated areas of rubble were the main habitats that showed little recovery over the course of 18 to 20 mo. The biomass of seagrass in the walls remained significantly less than in other habitats. The height of the walls decreased markedly during this time as the walls collapsed and merged with the surrounding substratum, but on 4 of the 5 transects the walls were still prominent. It is important to note that despite these prolonged effects, the walls and rubble banks only represented a very small component of the area across the mudflats. The greater proportion of the habitats in the areas being commercially harvested showed few prolonged (i.e. after 18 to $20 \mathrm{mo}$ ) effects from digging of bloodworms.

There were clear and distinct impacts on the abundance of benthic infauna in and around the commercial pits, and these effects were still detectable after 4 mo of recovery. The affected groups included gammarid amphipods, a range of different families of polychaetes, gastropods (primarily Velacumantus australis and Nassarius burchardi) and bivalves. These results are consistent with previous detailed studies on the effects of bait-harvesting on macrofauna, albeit in unvegetated sediments (McLusky et al. 1983, Van den Heiligenberg 1987). The most marked effects were observed for the habitat inside the commercial pits and on the walls raised during the digging process. This is not surprising, given the extent of the physical changes that occur in these habitats during harvesting. The area inside the pit is almost completely dug over, often to a depth $>1 \mathrm{~m}$, leaving unconsolidated and almost fluid mud except in the patches of undisturbed seagrass.

After $12 \mathrm{mo}$, there were no detectable differences in the abundances of infauna among the dug areas of a pit (inside, walls and outside) and the reference areas, suggesting infuana abundance had recovered in the commercially dug areas; however, this result should be treated with caution because of the potential effects arising from the outbreak of Lyngbya majuscula in western Moreton Bay. There were noticeable changes in the areas affected by the cyanobacterial mats, with fewer epibenthic animals present and extremely patchy distributions for many of the infauna. This resulted in $16 \%$ of the samples not containing any animals, and $40 \%$ containing less than 5 animals (the snail Batillaria australis represented most of the animals that were present). This pattern was not restricted to the area around the commercial pits, but extended across much of the southern end of Fisherman's Island (authors' pers. obs.). There have been few detailed ecological studies of the effects of L. majuscula on the faunal communities in seagrass, although the toxicity of the cyanobacterium on a range of other biota has been firmly established (e.g. Nagle \& Paul 1998, Dennison et al. 1999, reviewed by Osborne et al. 2001). The implications of the extensive coverage of $L$. majuscula across Fisherman's Island on the diverse community of plants and animals that are found in these habitats are unclear, but need to be taken into account when considering the apparent recovery of fauna in and around the commercial pits.

Very few bloodworm Marphysa spp. recruits or juveniles were detected in any of the samples in and around the commercial pits or in the reference areas during the study, consistent with the findings of Hopper (1994), who suggested that worms recruit subtidally, then migrate into intertidal habitats. If this is the case, then subtidal areas may provide an important refuge for populations of worms because these habitats are not harvested due to current restrictions on allowable harvesting methods (hand harvesting with pitchforks would not be feasible in the subtidal). Blake $(1979 a, b)$ found that recolonisation by Nereis virens also occurred from neighboring, unharvested areas. Vadas \& Bristow (1985) and Bristow \& Vadas (1991) studied gene flow and genetic changes in a heavily harvested population of Atlantic bloodworm Glycera dibranchiata, and found that there was restricted migration and colonisation from populations between and within estuaries and suggested that colonisation of intertidal areas was unlikely to occur from subtidal refuge populations, countering previous suggestions by Klawe \& Dickie (1957), Creaser (1973) and Creaser \& Clifford (1986). The presence of refuge populations of Marphysa spp. in the subtidal region of Fisherman's Island may be an important issue for the long-term viability of the fishery, if over-harvesting of the intertidal areas were to occur. Detailed genetic studies of subpopulations around Moreton Bay, in intertidal and subtidal areas, would be needed to determine this.

Despite the significant observed impacts of the digging of commercial pits on the habitats (seagrass and sediment) and infaunal community, the total area of Fisherman's Island that is affected at any time is relatively small. The total area of the 4 commercial plots on Fisherman's Island are: Area $1=918142.5 \mathrm{~m}^{2}$, Area $2=$ $438531.4 \mathrm{~m}^{2}$, Area $3=1083212.9 \mathrm{~m}^{2}$ and Area $4=$ $1288544.2 \mathrm{~m}^{2}$. At the time of this study, most commercial activity was based in Commercial Area 1, yet the total area within that plot that showed any signs of having been dug (i.e. modified habitat) was only $360931 \mathrm{~m}^{2}$, i.e. approximately $39 \%$ of the total. This represents the area contained within an outer perimeter bounding the overall section that had been dug over, but there was a great deal of the habitat within 
that perimeter that was intact (usually $>50 \%$ ). If the data from Commercial Area 1 are also representative of the pattern of digging in the other commercial plots, then approximately $20 \%$ of the available intertidal habitat within the commercial plots is being harvested at any time. As long as harvesters do not revisit a previously dug area for 18 to 24 mo-the time it takes for the habitat to recover to a significant extent - then the long-term sustainability of the commercial industry should be maintained.

Acknowledgements. This work was generously funded by the Fisheries Research and Development Corporation (Project 1998/224). We thank J. Doyle, K. Finnerty, S. Pittman, A. Pryor, F. Rohweder, J. Toon and S. Walker for help with field and laboratory work at various times during this project. The manuscript was greatly improved by comments from G. Chapman, S. Cummins, H. Lenihan, and N. Loneragan.

\section{LITERATURE CITED}

Abrams PA (1980) Resource partitioning and interspecific competition in a tropical hermit crab community. Oecologia 46: 365-379

Abrams PA, Nyblade C, Sheldon S (1986) Resource partitioning and competition for shells in a subtidal hermit crab species assemblage. Oecologia 69:429-445

Arnold WS (1984) The effect of prey size, predator size, and sediment composition on the role of predation of the blue crab, Callinectes sapidus Rothbun, on the hard clam, Mercenaria mercenaria (Linné). J Exp Mar Biol Ecol 80: 207-219

Barshaw DE, Able KW (1990) Deep burial as a refuge for lady crabs Ovalipes ocellatus: comparisons with blue crabs Callinectes sapidus. Mar Ecol Prog Ser 66:75-79

Bell JD, Pollard DA (1989) Ecology of fish assemblages and fisheries associated with seagrasses. In: Larkum AWD, McComb AJ, Shepherd SA (eds) Biology of seagrasses: a treatise on the biology of seagrasses with special reference to the Australian region. Elsevier, Amsterdam, p 565-609

Blake RW (1979a) Exploitation of a natural population of Arenicola marina (L.) from the north-east coast of England. J Appl Ecol 16:663-670

Blake RW (1979b) On the exploitation of a natural population of Nereis virens Sars from the north-east coast of England. Estuar Coast Mar Sci 8:141-148

Bowden DA, Rowden AA, Attrill MJ (2001) Effect of patch size and in-patch location on the infaunal macroinvertebrate assemblages of Zostera marina seagrass beds. J Exp Mar Biol Ecol 259:133-154

Brenchley GA (1981) Disturbance and community structure: an experimental study of bioturbation in marine soft-bottom communities. J Mar Res 39:767-790

Bristow GA, Vadas RL (1991) Genetic variability in bloodworm (Glycera dibranchiata) populations in the Gulf of Maine. Mar Biol 109:311-319

Brouns JJWM (1987) Growth patterns in some Indo-WestPacific seagrasses. Aquat Bot 28:39-61

Carriker MR (1986) Influence of suspended particles on biology of oyster larvae in estuaries. Am Malacol Bull Spec 3:41-49

Clarke SM, Kirkman H (1989) Seagrass dynamics. In: Larkum AWD, McComb AJ, Shepherd SA (eds) Biology of sea- grasses: a treatise on the biology of seagrasses with special reference to the Australian region. Elsevier, Amsterdam, p 304-345

Coen LD, Heck KL, Abele LG (1981) Experiments on competition and predation among shrimps of seagrass meadows. Ecology 62:1484-1493

Creaser EP (1973) Reproduction of the bloodworm (Glycera dibranchiata) in the Sheepscott Estuary. J Fish Res Board Can 30:161-166

Creaser EP, Clifford DA (1986) The size frequency and abundance of subtidal bloodworms (Glycera dibranchiata Ehlers) in Montsweag Bay, Woolwich-Wiscasset, Maine. Estuaries 9:200-207

Creed JC, Amado Filho GM (1999) Disturbance and recovery of the macroflora of a seagrass (Halodule wrightii Ascherson) meadow in the Abrolhos Marine National Park, Brazil: an experimental evaluation of anchor damage. J Exp Mar Biol Ecol 235:285-306

Dawes CJ, Andorfer J, Rose CUC, Ehringer N (1997) Regrowth of the seagrass Thalassia testudinum into propeller scars. Aquat Bot 59:139-155

Day JH (1967) Polychaeta of southern Africa. Part 1. Errantia. Part 2. Sedentaria. British Museum of Natural History, London

de Boer WF, Prins HHT (2002) The community structure of a tropical intertidal mudflat under human exploitation. ICES J Mar Sci 59:1237-1247

den Hartog C (1977) Structure, function and classification in seagrass communities. In: McRoy CP, Helfferich C (eds) Seagrass ecosystems: a scientific perspective. Marcel Dekker, New York, p 89-122

Dennison WC, O'Neill JM, Duffey EJ, Oliver PE, Shaw GR (1999) Blooms of the cyanobacterium Lyngbya majusculum in coastal waters of Queensland, Australia. Bull Inst Oceanogr (Monaco) 501-506

Dirnberger JM (1994) Influences of larval settlement location and rate on later growth and mortality in a sessile marine invertebrate population (Spirorbis spirillum). Northeast Gulf Sci 13:65-78

Duarte CM, Terrados J, Agawin NSR, Fortes MD, Bach S, Kenworthy WJ (1997) Response of a mixed Philippine seagrass meadow to experimental burial. Mar Ecol Prog Ser 147: 285-294

Dumbauld BR, Armstrong DA, McDonald TL (1993) Use of oyster shell to enhance intertidal habitat and mitigate loss of Dungeness crab (Cancer magister) caused by dredging. Can J Fish Aquat Sci 50:381-390

Eckrich CE, Holmquist JG (2000) Trampling in a seagrass assemblage: direct effects, response of associated fauna, and the role of substrate characteristics. Mar Ecol Prog Ser 201: 199-209

Fauchald K (1977) The polychaete worms: definitions and keys to the orders, families and genera. Science series 28. Natural History Museum of Los Angeles County, Los Angeles, CA

Fonseca MS (1989) Sediment stabilization by Halophila decipiens in comparison to other seagrasses. Estuar Coast Shelf Sci 29:501-507

Fonseca MS, Zieman JC, Thayer GW, Fisher JS (1983) The role of current velocity in structuring eelgrass (Zostera marina L.) meadows. Estuar Coast Shelf Sci 17:367-380

Fonseca MS, Kenworthy WJ, Colby DR, Rittmaster KA, Thayer GW (1990) Comparisons of fauna among natural and transplanted eelgrass Zostera marina meadows: criteria fo mitigation. Mar Ecol Prog Ser 65:251-264

Forbes AT (1984) The bait worm fishery in Moreton Bay, project report Q08009. Queensland Department of Primary Industries, Brisbane 
Ginsburg RN, Lowenstam HA (1958) The influence of marine bottom communities on the depositional environment of sediments. J Geol 66:310-318

Heck KL, Thoman TA (1981) Experiments on predator-prey interactions in vegetated aquatic habitats. J Exp Mar Biol Ecol 53:573-596

Hillman K, McComb AJ, Walker DI (1995) The distribution, biomass and primary production of the seagrass Halophila ovalis in the Swan Canning estuary, Western Australia. Aquat Bot 51:1-54

Hines AH, Comtois KL (1985) Vertical distribution of estuarine infauna in sediments in a subestuary of central Chesapeake Bay. Estuaries 8:296-304

Hopper GA (1994) The reproductive ecology and biology of Marphysa sanguinea (Annelida; Polychaeta), a fisheries resource. Honours thesis, University of Queensland, Brisbane

Keough MJ (1986) The distribution of a bryozoan on seagrass blades: settlement, growth and mortality. Ecology 67: 846-857

Klawe WL, Dickie LM (1957) Biology of the bloodworm Glycera dibranchiata Ehlers, and its relation to the bloodworm fishery of the maritime provinces. Bull Fish Res Board Can 115: $1-37$

Leber KM (1985) The influence of predatory decapods, refuge, and microhabitat selection on seagrass communities. Ecology 66:1951-1964

Maurer D, Keck RT, Tinsman JC, Leatham WA (1981a) Vertical migration and mortality of benthos in dredged material. Part I. Mollusca. Mar Environ Res 4:299-319

Maurer D, Keck RT, Tinsman JC, Leatham WA (1981b) Vertical migration and mortality of benthos in dredged material. Part II. Crustacea. Mar Environ Res 5:301-317

Maurer D, Keck RT, Tinsman JC, Leatham WA (1982) Vertical migration and mortality of benthos in dredged material. Part III. Polychaeta. Mar Environ Res 6:49-68

May EB (1973) Environmental effects of hydraulic dredging in estuaries. Alabama Mar Resour Bull 9:1-85

McLusky DS, Anderson FE, Wolfe-Murphy S (1983) Distribution and population recovery of Arenicola marina and other benthic fauna after bait-digging. Mar Ecol Prog Ser 11:173-179

Moriarty DJW, Boon PI (1989) Interactions of seagrasses with sediment and water. In: Larkum AWD, McComb AJ, Shepherd SA (eds) Biology of seagrasses: a treatise on the biology of seagrasses with special reference to the Australian region. Elsevier, Amsterdam, p 500-535

Nagle DG, Paul VJ (1998) Chemical defense of a marine cyanobacterial bloom. J Exp Mar Biol Ecol 225:29-38

Orth RJ, Heck KL, van Montfrans JV (1984) Faunal communities in seagrass beds: a review of the influence of plant structure and prey characteristics on predator-prey relationships. Estuaries 7:339-350

Osborne NJT, Webb PM, Shaw GR (2001) The toxins of Lyngbya majuscula and their human and ecological health effects. Environ Int 27:381-392

Peterson CH (1985) Patterns of lagoonal bivalve mortality after heavy sedimentation and their paleological significance. Paleobiology 11:139-153

Peterson CH, Summerson HC, Fegley SR (1987) Ecological consequences of mechanical harvesting of clams. Fish Bull 85: 281-298

Rasheed MA (1999) Recovery of experimentally created gaps within a tropical Zostera capricorni (Aschers) seagrass meadow, Queensland Australia. J Exp Mar Biol Ecol 235: $183-200$

Rhoads DC (1974) Organism-sediment relationships on the muddy sea-floor. Oceanogr Mar Biol Annu Rev 12:263-300

Editorial responsibility: Antony Underwood (Contributing Editor), Sydney, Australia
Rhoads DC, Young DK (1971) Animal-sediment relations in Cape Cod Bay, Massachusetts. II. Reworking by Molpadia oolitica (Holothuroidea). Mar Biol 11:255-261

Saila SB, Pratt SD, Polgar TT (1972) Dredge spoil disposal in Rhode Island Sound. Marine technical Rep No 2. University of Rhode Island, Kingston, RI

Sanders HL (1958) Benthic studies in Buzzard Bay. I. Animalsediment relationships. Limnol Oceanogr 3:245-253

Sanders HL (1960) Benthic studies in Buzzard Bay. III. The structure of the soft-bottom community. Limnol Oceanogr 5: $138-153$

Sand-Jensen K (1975) Biomass, net production and growth dynamics in an eelgrass (Zostera marina L.) population in Vellerup Vig, Denmark. Ophelia 14:185-201

Shepherd SA, McComb AJ, Bulthuis DA, Neverauskas V, Steffensen DA, West RJ (1989) Decline of seagrasses. In: Larkum AWD, McComb AJ, Shepherd SA (eds) Biology of seagrasses: a treatise on the biology of seagrasses with special reference to the Australian region. Elsevier, Amsterdam, p 346-387

Short FT, Wyllie-Echeverria S (1996) Natural and human-induced disturbance of seagrasses. Environ Conserv 23:17-27

Skilleter GA (1994) Refuges from predation and the persistence of estuarine clam populations. Mar Ecol Prog Ser 109:29-42

Skilleter GA (1996) An experimental test of artifacts from repeated sampling in soft-sediments. J Exp Mar Biol Ecol 205: $137-148$

Summerson HC, Peterson CH (1984) Role of predation in organising benthic communities of a temperate-zone seagrass bed. Mar Ecol Prog Ser 15:63-77

Thistle D (1981) Natural physical disturbances of marine softbottoms. Mar Ecol Prog Ser 6:223-228

Vadas RL, Bristow G (1985) Genetic changes associated with a bottleneck in an overharvested population of Glycera dibranchiata (Polychaeta). In: Gray JS, Christiansen ME (eds) Marine biology of polar regions and effects on marine organisms. Wiley Interscience, Chichester, p 617-629

Van den Heiligenberg T (1987) Effects of mechanical and manual harvesting of lugworms Arenicola marina L. on the benthic fauna of tidal flats in the Dutch Wadden Sea. Biol Conserv 39:165-177

Vermaat JE, Agawin NSR, Duarte CM, Fortes MD, Marbá N, Uri JS (1995) Meadow maintenance, growth and productivity of a mixed Philippine seagrass bed. Mar Ecol Prog Ser $124: 215-225$

Ward TJ (1989) The accumulation and effects of metals in seagrass habitats. In: Larkum AWD, McComb AJ, Shepherd SA (eds) Biology of seagrasses: a treatise on the biology of seagrasses with special reference to the Australian region. Elsevier, Amsterdam, p 797-820

WBM Oceanics (1993) The Fisherman's Island baitworm fishery Brisbane's port environmental study. Port of Brisbane Authority, Brisbane, p 193-204

Wildish DJ, Thomas MLH (1985) Effect of dredging and dumping on benthos of Saint John Harbour, Canada. Mar Environ Res 15:45-58

Woodin SA (1979) Settlement phenomena: the significance of functional groups. In: Stancyk SE (eds) Reproductive ecology of marine invertebrates. University of South Carolina Press, Columbia, SC, p 99-106

Zharikov Y, Skilleter GA (2004) Potential interactions between humans and non-breeding shorebirds on a subtropical intertidal flat. Aust Ecol 29:647-660

Zieman JC (1976) The ecological effects of physical damage from motor boats on turtle grass beds in southern Florida. Aquat Bot 2:127-139

Submitted: October 6, 2004; Accepted: August 9, 2005

Proofs received from author(s): January 3, 2006 